\title{
Groundwater isoscapes in a montane headwater catchment show dominance of well-mixed storage
}

\begin{tabular}{|r|l|}
\hline Journal: & Hydrological Processes \\
\hline Manuscript ID & HYP-17-0187.R1 \\
\hline Wiley - Manuscript type: & Research Article \\
\hline Complete List of Authors: & $\begin{array}{l}\text { Scheliga, Bernhard; University of Aberdeen, Northern Rivers Institute, } \\
\text { School of Geosciences } \\
\text { Tetzlaff, Doerthe; University of Aberdeen, Northern Rivers Institute, School } \\
\text { of Geosciences } \\
\text { Nuetzmann, Gunnar; IGB, Dept. of Ecohydrology } \\
\text { Soulsby, Chris; University of Aberdeen, School of Geosciences }\end{array}$ \\
\hline Keywords: & groundwater, stable isotopes, isoscapes, Ic-excess \\
\hline &
\end{tabular}

SCHOLARONE"

Manuscripts 
1 Groundwater isoscapes in a montane headwater catchment

2

3

4

5

\title{
show dominance of well-mixed storage
}

\author{
B. Scheliga, D. Tetzlaff, G. Nuetzmann and C. Soulsby
}

Northern Rivers Institute, School of Geosciences, University of Aberdeen, AB24 3UF, UK

\section{Abstract}

We conducted an integrated groundwater - surface water monitoring programme in a 3.2 $\mathrm{km}^{2}$ experimental catchment in the Scottish Highlands by sampling all springs, seepages and wells in six, spatially extensive synoptic surveys over a two year period. The catchment has been glaciated, with steep hillslopes and a flat valley bottom. There is around $70 \%$ glacial drift cover in lower areas. The solid geology, which outcrops at higher elevations, is granite and metamorphic schist. The springs and seepages generally occur at the contact between the solid geology and drift or at breaks of slopes in the valley bottom. Samples were analysed for stable isotopes, Gran alkalinity and electrical conductivity (EC). Despite the surveys encompassing markedly different antecedent conditions, the isotopic composition of groundwater at each location exhibited limited temporal variability, resulting in a remarkable persistence of spatial patterns indicating well-mixed shallow, groundwater stores. Moreover, Ic-excess values derived from the isotope data indicated no evidence of fractionation affecting the groundwater, which suggests that most recharge occurs in winter. The alkalinity and EC of groundwater reflected geological differences in the 
1 catchment, being highest where more weatherable calcareous rocks outcrop at higher

2 altitudes in the catchment. Springs draining these areas also had the most variable isotope

3 composition, which indicated that they have shorter residence times than the drift covered

4 part of the catchment. The study showed that even in geologically heterogeneous upland

5 catchments, groundwater can be characterised by a consistent isotopic composition,

6 reflecting rapid mixing in the recharge zone. Our work, thus, emphasises the critical role of

7 groundwater in upland catchments and provides tracer data that can help constrain

8 quantitative groundwater models.

10 Keywords: groundwater, stable isotopes, isoscapes, Ic-excess

\section{1. Introduction}

13 Groundwater dynamics are an important influence on the ecohydrology of montane

14 headwater catchments, as well as being critical for ensuring provision of water supplies for

15 downstream ecosystems and human use especially during low flow conditions (Frisbee et

16 al., 2011; Gleeson et al., 2012; Batlle-Aguilar et al., 2014). Recent studies show that

17 groundwater contributions to the stream flow in montane regions are often surprisingly

18 high (Jasechko et al., 2016) and can frequently account for over half of the annual runoff

19 (e.g. Soulsby et al., 1998; Birkel et al., 2011a; Šanda et al., 2014). Where mountainous

20 catchments have been affected by glaciation, they are often covered by drift deposits that

21 contrast in size and aquifer properties. These drift deposits often exert a strong influence on

22 the spatial patterns of groundwater recharge and storage (Soulsby et al., 2004). Whilst such

23 drift deposits and the underlying bedrock are usually relatively poor aquifers (Soulsby et al.,

24 2000; Aishlin and McNamara, 2011), the dynamics of these groundwater stores are complex 
1 and play a critical role in stream flow generation (Neal et al., 1997; Soulsby et al., 1998;

2 Haria and Shand, 2004).

3

4 Research into groundwater in high altitude terrain faces a number of logistical obstacles.

5 Installation of boreholes to sufficiently capture the high level of heterogeneity in the

6 subsurface is often impractical and expensive due to inaccessibility for drilling equipment

7 (Gabrielli and McDonnell, 2012). The remote terrain also usually makes it difficult to even

8 just collect water samples from springs and seepages across a catchment (Soulsby et al.,

$92004,2007)$. Nevertheless, synoptic sampling of such groundwater sources and analysis for

10 tracers like stable isotopes and geochemicals to identify and differentiate water sources and

11 flow paths, as well as the temporal dynamics of their contribution to runoff generation has

12 become common practice in catchment hydrology (Neal et al., 1997; Kendall and

13 McDonnell, 1998; Tetzlaff and Soulsby, 2008; Barthold et al., 2011; Lessels et al., 2016).

15 In low-temperature environments, once the sources of atmospheric moisture determining 16 precipitation composition are accounted for, the isotopic characteristics of natural waters 17 are governed by physical processes, specifically phase changes (evaporation, condensation 18 and melting) above or near the ground surface, as well as mixing in the subsurface 19 (Leibundgut et al., 2009). Recent studies have started to use spatially distributed isotope 20 data derived from synoptic sampling campaigns to map "isoscapes" of groundwater isotope 21 composition (and related derivatives such as d- and lc-excess which can infer fractionation) 22 (Darling et al., 2003; Wassenaar et al., 2009; West et al., 2014; Raidla et al., 2016). Isoscape 23 maps are derived from an iterative, multistep process using isotopic information combined 24 with other geospatial data (Bowen and West, 2008), to facilitate the spatial description of 
1 landscapes according to isotopic variation. These maps can then be used to infer recharge,

2 mixing processes, and other associated controls and how these are reflected in the spatial

3 and temporal heterogeneity of the isoscape (Sánchez-Murillo and Birkel, 2016). Other tracer

4 compositions can also be mapped. For example, alkalinity or various geochemicals can be

5 useful tracers to identify the geological sources of groundwater as they are indices of

6 weathering and/or residence times, being higher where more calcareous or other base-rich

7 rocks are present or contact times are longer (Haria and Shand, 2004; Birkel et al., 2011b).

8

9 Over the past decade, intensive research at the Bruntland Burn, a tributary of the Girnock

10 research catchment in the Scottish Highlands, has increased our understanding of

11 groundwater in montane headwaters by utilizing isotope tracer analyses in conjunction with

12 hydrometric monitoring and integration in models (Tetzlaff et al., 2014; Soulsby et al.,

13 2015). Tracer-aided models using high-resolution isotope data suggest that about $35 \%$ of

14 stream flow is attributable to deeper groundwater sources (Birkel et al., 2011a). Synoptic

15 sampling in valley bottom areas, combined with geospatial analysis, identified the location

16 of groundwater exfiltration in the extensive riparian zone (Lessels et al., 2016). This has

17 corroborated 3-D groundwater - surface water models which predict areas of groundwater

18 exfiltration (Ala-aho et al., 2017). However, a catchment-scale assessment of the isotopic

19 composition of groundwater, contextualised according to changes in groundwater storage is

20 still a research gap.

21

22 This paper uses isoscapes to assess groundwater dynamics in the headwater catchment of

23 the Bruntland Burn, via establishing the spatial and temporal variability in the isotopic

24 composition of groundwater. We specifically aimed to: 
1 (1) Use stable isotopes - together with other tracers - within a broader framework of hydrometric monitoring to assess the dynamics of groundwater recharge,

(2) Use synoptic surveys to assess the spatio-temporal variability of stable isotopes in all major groundwater springs, seepages and boreholes,

(3) Provide qualitative insights into the sources and residence times of groundwater in different parts of the catchment.

$8 \quad$ 2. Study site

9 The Bruntland Burn (Figure 1) is a $3.2 \mathrm{~km}^{2}$ headwater of the $30 \mathrm{~km}^{2}$ Girnock Burn in the 10 Cairngorms National Park in NE Scotland. The Girnock is a sub-catchment of the River Dee $11\left(\sim 2108 \mathrm{~km}^{2}\right)$ the largest UK catchment without a regulating reservoir. The Dee supports an 12 economically important Atlantic salmon (Salmo salar) fishery and provides drinking water 13 for more than 300.000 people (Tetzlaff et al., 2012). The climate is transitional between northern temperate and boreal, but with a maritime influence, which leads to mild winters and cool summers. Average annual air temperature is around $6{ }^{\circ} \mathrm{C}$ with a daily average of 1 ${ }^{\circ} \mathrm{C}$ and $12{ }^{\circ} \mathrm{C}$ in winter and summer, respectively. Precipitation $(P)$ is evenly distributed

17 throughout the year with an annual average of $1100 \mathrm{~mm}$ (1993-2015 at Balmoral, ca $5 \mathrm{~km}$ 18 west of the catchment). About $50 \%$ of $P$ falls during frequent, low intensity events of $<10$ $19 \mathrm{~mm} \mathrm{~d}^{-1}$. Three quarter of all events are below $20 \mathrm{~mm} \mathrm{~d}^{-1}$. Approximately $5 \%$ of annual P 20 generally falls as snow. During colder years, this can exceed $10 \%$. The mean annual 21 potential evapotranspiration (ET) and runoff (R) are around $400 \mathrm{~mm}$ and $700 \mathrm{~mm}$, 22 respectively (Birkel et al., 2011b). It is estimated that $25-35 \%$ of the annual discharge is 23 sustained by groundwater (Birkel et al., 2011a, 2011b), though overland flow during 
1 precipitation events dominates the generation of the storm hydrograph which characterises

2 the flashy flow regime.

3

4 The catchment is of glacial origin with a wide flat valley bottom and steep hillslopes, with

5 slopes up to $61^{\circ}$ and a mean gradient of $14^{\circ}$; the elevation ranges from $238-539 \mathrm{~m}$ a.s.l.

6 (Figure 1a and Figure 2). Most of the underlying bedrock in the catchment is granite, with

7 Ca-rich and Si-rich meta-sediments (Figure 1b). Glacial drift deposits cover large parts of the

8 catchment (about $70 \%$ ) reaching up to $40 \mathrm{~m}$ of depth in the valley bottom where this drift

9 overlays the bedrock (Soulsby et al., 2007). In the valley bottom, the drift is comprised of a

10 silty-sand matrix with abundant larger clasts and has low permeability. In contrast, the

11 steeper hillslopes are veiled by shallower ( $5 \mathrm{~m}$ deep), more permeable lateral moraines

12 and ice marginal deposits (Soulsby et al., 2016).

13

14 Approximately $30 \%$ of the catchment is covered by organic-rich peat soils (Figure 1c) which

15 are $<0.5 \mathrm{~m}$ deep on the lower hillslopes, and up to $4 \mathrm{~m}$ deep in the valley bottom (Tetzlaff

16 et al., 2007). These soils are water retentive resulting in a quasi-permanently saturated

17 riparian zone, which is supplied by groundwater seepage from the upper hillslopes (Tetzlaff

18 et al., 2014). The saturated area in the valley bottom can range from $2-40 \%$ of the

19 catchment area, depending on the antecedent wetness conditions (Birkel et al., 2010). The

20 riparian zone has a small dynamic storage range (any soil moisture deficits are usually $<20$

$21 \mathrm{~mm}$ ) and is highly responsive towards precipitation events in terms of generating

22 saturation-excess overland flow (Soulsby et al., 2015). The water table in the peat soils is

23 usually within $0.2 \mathrm{~m}$ of the soil surface (Blumstock et al., 2016). Steeper hillslopes are

24 characterized by free draining podzols, which cover about $55 \%$ of the catchment. These 
1 mostly drain vertically and sustain groundwater recharge and slow downslope seepage.

2 Rapid lateral flow may occur during unusually wet periods if the organic rich upper horizons

3 become saturated and connected (Geris et al., 2015). Here, the water table depths can vary

4 but is usually between 0.4 and $1.5 \mathrm{~m}$ below the surface during wetter condition and

5 prolonged dry conditions, respectively (Tetzlaff et al., 2014). On the upper catchment

6 interfluves, shallow regosols with limited storage predominate (Figure 2).

7

8 The vegetation on the hillslope is dominated by heather (Calluna vulgaris), while Sphagnum

9 spp. and Molinia caerulea dominate the landscape in the riparian areas. Only $11 \%$ of the

10 catchment is covered with forest, mainly Scots pine (Pinus sylvestris) in plantations or on

11 more inaccessible hillslopes (Figure 1d). Over most of the catchment, heavy grazing by high

12 red deer populations prevents tree regeneration and maintains the dominant moorland 13 vegetation.

\section{Data and methods}

The basic hydrometric monitoring of the Bruntland Burn includes precipitation recorded at a weather station (Figure 1) using a tipping bucket rain gauge connected to a CR800 Campbell logger with a resolution of $0.2 \mathrm{~mm}$ and $15-\mathrm{min}$ intervals. Stage height was recorded with an Odyssey capacitance logger (resolution of around $0.8 \mathrm{~mm}$ ) at the outlet of the catchment (Figure 1). Discharge was derived from a regularly updated stage-discharge rating curve.

A core groundwater monitoring programme in the catchment has been focused around a hillslope transect where boreholes monitor water table fluctuations in the upper drift in the main landscape positions (Figures 1). Previous work has shown that this gives a broadly 
1 representative insight into water table levels over the wider catchment (Blumstock et al.,

2 2016). Between August 2015 - September 2016, we monitored water levels in four (>1.8 m)

3 wells (DW) along the hillslope transect (cf Figure 2), from the valley bottom up to the

4 hillslope top (north to south). We refer to these dwells as deep wells (DW) that were drilled

5 to differentiate them from earlier shallow wells installed by hand augering. However, we

6 recognise that this is a relative term. The boreholes were drilled using a handheld petrol

7 powered drill (Gabrielli and McDonnell, 2012) and the characteristics of the four wells (DW

81 - DW 4) are summarised in Table 1. The number and depth of the boreholes were limited

9 by the sandy-silt matrix of glacial drift which tended to collapse once wells reached around 2

$10 \mathrm{~m}$ depth. Hence, the successfully installed wells reach about $330 \mathrm{~cm}$ depth in the valley

11 bottom and $\sim 200 \mathrm{~cm}$ depth in the upper hillslope top, piercing into the upper layer of the

12 underlying drift. The wells were constructed from a PVC pipe with a diameter of $2.2 \mathrm{~cm}$ and

13 a screen covering the lower $30 \mathrm{~cm}$. We applied clean gravel in the spacing between

14 borehole walls and pipes to cover the screened section and above this, we used bentonite

15 to seal the wells.

17 In DW 1 and DW 2, groundwater is effectively confined beneath the deeper low 18 permeability peat layers, which have additionally formed over a $10 \mathrm{~cm}$ deep, intensively 19 weathered layer with a more silty/clay texture, which overlies the coarser drift beneath. As 20 a result of this and the lower permeability of the deeper peat, shallower wells within the 21 peat show a perched water table that is usually within the upper $20 \mathrm{~cm}$ of the soil profile 22 (Blumstock et al., 2016). The groundwater at DW 3 and DW 4 is unconfined. 
1 We deployed micro-divers in all four wells and recorded the pressure head and temperature

2 at 15 minutes intervals. Data were verified with manual measurements on each site visit.

3 The precision of the divers was $\pm 1.0 \mathrm{~cm}$ for water levels and $\pm 0.1^{\circ} \mathrm{C}$ for temperature and the

4 resolution was $0.2 \mathrm{~cm}$ and $0.01{ }^{\circ} \mathrm{C}$, respectively. We also used a BaroDiver to correct

5 readings by recording the air pressure in 15 minutes intervals with an accuracy of \pm 0.5

$6 \mathrm{cmH}_{2} \mathrm{O}$ and a resolution of $0.1 \mathrm{cmH}_{2} \mathrm{O}$. The wells were sampled for stable isotopes and

7 hydrochemistry on approximately a monthly basis. However, the low temperatures during

8 winter precluded sampling as the upper part of the water column in the wells was frozen.

9 We used a battery powered pump to extract the samples. Before samples were taken, each

10 well was pumped empty and allowed $2 \mathrm{hrs}$ to refill before a sample was collected.

12 To extrapolate a wider understanding of the isotopic and solute composition of catchment 13 groundwater, we also conducted synoptic surveys to assess the spatio-temporal variability 14 of all perennial springs and seeps. On six occasions with contrasting seasonality and 15 antecedent wetness between October 2014 - July 2016 (see Figure 3 for the timings), we 16 sampled 20 springs or groundwater seepages spatially distributed across the catchment, 17 which form the sources of surface water tracks. Eleven of these are located on the upper 18 hillslopes in the south and southwest of the catchment (S 1 - S 11) and the remaining nine (S 1912 - S 20) are located along the valley bottom in the north (Figure 1c). The former upper 20 sampling sites are generally at the contact between the outcropping soil geology and the 21 drift where groundwater exfiltrates. The latter, valley bottom sampling sites are generally in 22 drift covered areas, but where there is a break in slope between the steeper hillslopes and 23 the flatter saturated peatland. We recorded the GPS coordinates of the springs and 
1 seepages with a GARMIN eTrex 10 handheld GPS. The landscape characteristics of the wells,

2 springs and seepages locations are shown in Table 2.

3

4 All water samples taken from the wells, seepages and springs were stored in $250 \mathrm{ml} \mathrm{PVC}$

5 bottles for transportation to the laboratory where they were stored in a fridge until they

6 were analysed. All spring/seepage samples were analysed for stable water isotopes, Gran

7 alkalinity and electrical conductivity (EC). The samples from the deeper wells could only be

8 analysed for isotopic composition as the use of bentonite as a sealing agent was found to

9 leach $\mathrm{Na}$ and $\mathrm{Ca}$ and influence the alkalinity and EC analysis. The isotopic composition was

10 analysed with a Los Gatos IWA-35d-EP Laser Spectrometer (precision of $\pm 0.3 \%$ for $\delta^{2} H ; \pm$

$110.1 \%$ for $\delta^{18} \mathrm{O}$ ) following a standard measuring protocol, by analysing a reference sample

12 every three water samples. The Post Analysis Software developed by Los Gatos is able to

13 detect and quantify organic contamination in the samples and if necessary, flagged samples

14 were filtered and re-analysed. Isotopic values are reported in $\delta$-notation (in \%o), the

15 abundance ratio of heavy to light isotope of a sample relative to the Vienna Standard Mean

16 Ocean Water (VSMOW). As Gran alkalinity closely approximates the conservative acid

17 neutralizing capacity (ANC), it can be used to distinguish hydrological sources in UK uplands

18 (Neal, 2001). Analysis followed Neal et al. (1997) using acidimetric Gran titration to end

19 points 4.5, 4.0 and 3.0. Electrical conductivity measured using a portable Hach hand-held

20 meter (corrected for temperature).

21

22 The effects of evaporative fractionation on groundwater samples were assessed by dual

23 isotope plots. This analysis uses the isotopic composition of precipitation, which is

24 characterized by equilibrium fractionation, leading to a strong correlation between $\delta^{18} \mathrm{O}$ and 
$1 \delta^{2} \mathrm{H}$ (Dansgaard, 1964) described locally by the local meteoric water line (LMWL). This

2 represents the regression of the dual isotope plot (LMWL for the BB: $\delta^{2} \mathrm{H}=7.6 \times \delta^{18} \mathrm{O}+4.7$ ).

3 The ratio between $\delta^{18} \mathrm{O}$ and $\delta^{2} \mathrm{H}$ can change during evaporation as a result of kinetic fraction

4 processes (Craig et al., 1963). Thus, samples affected by evaporation fractionation will plot

5 below the LMWL. As more water evaporates, the residual water becomes more kinetically

6 fractionated. These samples will increasingly deviate from the LMWL and their regression

7 line will have a lower slope. This regression line is the evaporation water line (EWL). The

8 resulting deviation from the LMWL is described as the line-conditioned excess (Ic-excess) as

9 defined by Landwehr and Coplen (2006):

$10 \quad l c-$ excess $=\delta^{2} H-a \times \delta^{18} O-b$

11 with $a$ and $b$ representing the slope and intercept of the LMWL (for BB: $a=7.6 ; b=4.7 \%$ ). To

12 assess if fractionation of groundwater occurs in different parts of the catchment, Ic-excess

13 was derived for all water samples.

15 Geospatial analysis was carried out for catchment assessment and to produce isoscape 16 maps. The topographic wetness index (TWI) was derived from a $1 \times 1 \mathrm{~m}$ digital terrain model 17 (DTM), based on high resolution LiDAR imagery using SAGA GIS. Most data processing was 18 carried out using the programming language $\mathrm{R}$ (version 3.3.1). We used inverse distance 19 weighting (IDW) to estimate the spatial distribution of each single tracer sample based on 20 the tracer values of the sampling points creating isoscapes of each sampling date. The IDW 21 was performed on a $10 \mathrm{~m}^{2}$ grid of the catchment using the idw()-function of the gstat 22 Package (v. 1.1-5) for R. We also calculated the mean prediction error (MPE) based on a 23 leave-one-out cross validation (loocv) for each sampling date to evaluate the spatial 
1 predictions from the IDW method. Using loocv, where successively one data point was left

2 out of the spatial prediction and used for validation (Arlot and Celisse, 2010), we were able

3 to compare predicted values for each sampled location with the measured tracer values for

4 the respective day. Kendall-Tau rank correlation was used to investigate the relationships

5 between the different tracers and the landscape characteristics, with values between - 1 to 1

6 and low correlations being around 0 and high ones close to either 1 or -1 . However, the

7 Kendell tau test showed no correlations between $\delta^{2} \mathrm{H}$, Ic-excess, alkalinity and electrical

8 conductivity, and the two landscape characteristics elevation and topographic wetness

9 index. Therefore, the interpolation of the tracers across the catchment to produce the

10 isoscape maps was done without accounting for the landscape characteristics.

\section{4. Results}

$13 \quad 4.1$ Temporal hydroclimatic background and groundwater dynamics

14 For most of the study period, precipitation events were fairly evenly distributed, mainly in

15 low intensity events $<10 \mathrm{~mm} \mathrm{~d}^{-1}$ (Figure 3a), with half of the daily rain events inputting $<1.5$

$16 \mathrm{~mm} \mathrm{~d}^{-1}$ to the catchment. Larger events $\left(>20 \mathrm{~mm} \mathrm{~d}^{-1}\right)$ occurred in October and November

172014 , July 2015, and June-July 2016. However, the most notable period of high precipitation

18 inputs occurred during an exceptionally wet period from early-December 2015 to early

19 January 2016. Between the $1^{\text {st }}$ December 2015 and $15^{\text {th }}$ January 2016, total rainfall

20 exceeded $375.2 \mathrm{~mm}$. These winter rainfall amounts in NE Scotland are unprecedented in the

21 period of data record (since 1890) and the return period is estimated to be $>200$ years

22 (Marsh et al. 2016). It is also notable that the precipitation occurred during an exceptionally

23 mild period, at a time of the year when precipitation might be expected to be mostly snow

24 above $250 \mathrm{~m}$ (Soulsby et al., 2017). 
2 The unusual (for the area) high intensity and long duration of precipitation resulted in high, 3 sustained discharge peaks during the December 2015 - January 2016 period (Figure 3a). For

412 days during December 2015 and the first three weeks of January 2016, the discharge 5 exceeded $10 \mathrm{~mm} \mathrm{~d}^{-1}$. The highest daily precipitation and discharge were recorded on the $630^{\text {th }}$ December 2015 with $56.7 \mathrm{~mm}$ and $25.8 \mathrm{~mm}$, respectively. During summer, lower rainfall

7 inputs and modest soil moisture deficits usually result in less marked event responses. The 8 lowest discharge was during summer at the end of the study period on the $27^{\text {th }}$ August 2016 9 with $0.08 \mathrm{~mm} \mathrm{~d}^{-1}$. Over the entire study period, $Q_{95}$ and $Q_{5}$ were $0.11 \mathrm{~mm} \mathrm{~d}^{-1}$ and $6.24 \mathrm{~mm}$ $10 d^{-1}$, respectively.

The groundwater records from the deeper wells coincide with the period August 2015 to 13 September 2016 and thus, encompass the wettest and driest spells in the two year record 14 (Figure 3 and Table 3). The water table dynamics of the riparian wells in the valley bottom 15 (DW $1-2$ ), where peat soils are dominant, were similar in response to precipitation events and subsequent drying (Figure $3 b$ ). In the first three months of the study, the water level in

17 DW 1 fluctuated between being just slightly above or below the ground surface and was 18 consistently highest of all wells. DW 2 generally had water levels around $10 \mathrm{~cm}$ below the ground surface, but rose several centimetres in response to events. Given the confined nature of these wells, they were indicative of vertically upwards hydraulic gradients in the deeper groundwater that discharges into the stream (Ala-aho et al., 2017). In the lower slope area, where peaty gley soils predominate at DW 3, the water table was deeper and unconfined (fluctuating between -20 to $-30 \mathrm{~cm}$ below the ground surface, depending on precipitation). On the upper hillslope, where freely draining podzols are dominant, DW 4 
1 had a much deeper water level (up to around $-1 \mathrm{~m}$ ) and exhibited the most dynamic

2 responses to precipitation events, with rapid rises (to the soil surface in the larger events)

3 followed by slower water table declines.

4

5 As with the stream flow record, the well hydrographs were dominated by the wet December

62015 / January 2016 period. All wells recorded their highest water table at this time, and all

7 wells - except DW 3 - showed artesian behaviour. DW 1 and DW 2 peaked both on the $30^{\text {th }}$

8 December 2015 with $31 \mathrm{~cm}$ and $16 \mathrm{~cm}$ above the surface, respectively. The higher head in

9 DW 1 likely reflected a more marked hydraulic gradient given the close proximity of the

10 steep hillslope to the north, DW 3 had its highest recorded water table of $-2.5 \mathrm{~cm}$ below the

11 surface on the $4^{\text {th }}$ January 2016, but remained high. The well on the hillslope top (DW 4)

12 plateaued for 22 days starting the $24^{\text {th }}$ December 2015 till the $14^{\text {th }}$ January 2016 before its

13 water table fell below the upper soil profile and then rapidly declined again.

15 The decline in water levels following a drier mid-January was punctuated by a wet end to 16 the month and increased water levels again, especially at DW 4. All rainfall events over the 17 next four months yielded daily totals of $<20 \mathrm{~mm}$, and water tables gradually fell in all wells, 18 though the recessions were briefly reversed several times in relation to modest rainfall 19 events. However, DW 1 continued to be artesian, and the water level in DW 2 only fell 20 below the soil surface in May 2016, whilst DW 3 and DW 4 had respective water levels at 21 around $-25 \mathrm{~cm}$ and $-105 \mathrm{~cm}$ below the surface in early June 2016 . A large $(>40 \mathrm{~mm})$ rainfall 22 event occurred in mid-June 2016 , producing a major ( $>15 \mathrm{~mm} \mathrm{~d}^{-1}$ ) runoff response. This 23 again resulted in artesian conditions in DW 2 and the water levels in DW 3 and DW 4 rose by 20 and $100 \mathrm{~cm}$, respectively. Declines were rapid, though reversed by several smaller events 
1 in late June and July 2016, though the dynamics in each well were similar to the recession

2 after the December 2015/January 2016 wet period.

4 The lowest water levels for most wells were recorded in the summer of 2015. Both, DW 1

5 and DW 3 had their lowest water table on the $11^{\text {th }}$ September 2015 with $-4.3 \mathrm{~cm}$ and -37.4

$6 \mathrm{~cm}$ below the surface, respectively. DW 2 recorded its lowest value on the $13^{\text {th }}$ August 2015

7 with $-20.4 \mathrm{~cm}$ below the surface. However, the lowest water table in DW 4 with $-108.9 \mathrm{~cm}$

8 below the surface was recorded on the $14^{\text {th }}$ June 2016 after a period of 3 weeks with little

9 rain. Standard deviations (Table 3) of the water tables in DW 2 and DW 3 were very similar

10 with $7.2 \mathrm{~cm}$ and $7.1 \mathrm{~cm}$, respectively. DW 1 displayed the lowest and DW 4 the highest

11 standard deviation with $5.5 \mathrm{~cm}$ and $31.9 \mathrm{~cm}$, respectively.

13 Water temperatures in the wells were remarkably damped, despite the water level changes

14 and showed smooth variation in response to climatic seasonality (Figure 3c). The highest

15 ranges and standard deviations were exhibited by DW 3 followed by DW 4 (Table 3). As for

16 the water levels, temperatures in DW 1 and DW 2 were very damped and consistent. This

17 seems to reflect a stronger influence of seasonal variation in recharge temperatures at DW

183 and DW 4, albeit damped compared to air temperatures, exhibiting about half the range.

19 In DW 1 and DW 2, the seasonal variation more likely reflects seasonality of advective heat

20 transfer from the atmosphere.

224.2 Dynamics of stable isotopes and hydrochemistry

23 Figure $3 \mathrm{~d}$ shows the daily variation in $\delta^{2} \mathrm{H}$ precipitation and stream flow between 24 September 2014 and August 2016. Whilst precipitation shows expected seasonality of being 
1 depleted in heavier isotopes in winter and enriched in summer, day-to-day variation can be

2 marked in any season. In contrast, streamflow is dramatically damped (standard deviation

3 of stream flow $\delta^{2} \mathrm{H}$ is $2.5 \%$ compared to $24.2 \%$ for precipitation), though the seasonality

4 of inputs is generally evident as well as day-to-day variability in response to some

5 hydrological events.

6

7 In Figure 4, all the precipitation, groundwater and stream samples for the Bruntland Burn

8 are plotted in dual isotope space. Naturally, precipitation samples (Figure 4a) showed the

9 widest range, plotting along the local meteoric water line (LMWL), which is close to the

10 global meteoric water line (GMWL). The stream water samples (Figure $4 \mathrm{~b}$ ) plotted within a

11 much narrower range and with some deviation from the LMWL, especially in more enriched

12 summer samples, which show evidence of secondary evaporative fractionation (Sprenger et

13 al., 2017). The spatially distributed samples of seepage and spring waters (Figure 4c) and

14 deeper groundwater from the wells (Figure 4d) exhibit a narrower range than stream water.

15 Such limited variability is surprising given the spatial extent of the sample locations, the

16 heterogeneity in geology and drift cover, as well as the range of antecedent conditions prior

17 to sampling. They also plot towards the same space as the more depleted stream water

18 samples, though some stream water samples are much more depleted in winter storm

19 events than any groundwater samples (cf Figure 4b). The groundwater samples also plot

20 close to GMWL and LMWL, with many plotting slightly above as a result of winter recharge,

21 and show no evidence of evaporative fractionation.

23 Figure 5 shows the boxplots for stable water isotopes measured in the wells and springs over the study period, as well as alkalinity and EC. Given that the wells were sampled at 
1 approximately monthly intervals over a 12 month period, and the springs and seeps were

2 sampled on six occasions with contrasting antecedent conditions, the isotope composition

3 was remarkably consistent at almost all sites. Across the catchment, the median values of all

4 sampling locations were within about $5 \%$ for $\delta^{2} \mathrm{H}$ and $1 \%$ for $\delta^{18} \mathrm{O}$ (Table 4). Overall,

5 compositions in DW 2 and DW 3 were slightly more enriched than in DW 1 and DW 4 . In the

6 upper hillslope, DW 4 displayed the largest range in $\delta^{2} \mathrm{H}$ and was the most depleted of the

7 deeper wells. Comparing the spring samples, most locations were very consistent with low

8 isotopic variability in space and time, with all but three sites having standard deviations $<1.6$

$9 \%$ for $\delta^{2} \mathrm{H}$ and two sites $<0.5 \%$ for $\delta^{18} \mathrm{O}$. However, the springs in the upper part of the

10 catchment at higher altitudes and without glacial drift cover tended to have higher isotopic

11 variability (e.g. S 9, S 10 and S 11). Groundwater at most sampling sites was less variable and

12 more depleted compared to stream water (2.5\%o standard deviation and a median of -57.5

$13 \%$ for $\delta^{2} \mathrm{H} ; 0.4 \%$ standard deviation and a median of $-8.5 \%$ for $\delta^{18} \mathrm{O}$ ).

15 The lc-excess of precipitation can be highly variable, with average values close to zero (Table 16 4). Apart from very rare exceptions, the Ic-excess in stream water at the BB outlet and in all 17 groundwater samples was consistently greater than zero, indicating no effect of evaporative 18 fractionation took place and suggesting moisture sources dominated by winter recharge 19 (Landwehr and Coplen, 2006). The mean and median values for groundwater samples were 20 all quite similar (Table 4 and Figure $5 c$ ). Highest median Ic-excess values were found in S 2, S 213 and S 17 with values above $6 \%$. Lowest median Ic-excess values were found at S 7, S 9, S 2212 , S 14, S 18 and S 20 with values below $3 \%$. Highest standard deviation was at S9 (which 23 was similar to precipitation), lowest in S 10 and S 14. 
1 In contrast to the isotopes, alkalinity showed greater variability across the sites in space

2 (Figure 5d). This largely reflected differences in the underlying solid geology, with sites

3 draining the drift-free meta-sediments in the south and west of the catchment (Figure b)

4 like S 7, S 8, S 9 and S 11 having the highest alkalinities with median values up to $>200 \mu \mathrm{EqI}^{-1}$

5 (Table 4). Most of the seepages showed median values between $85 \mu \mathrm{Eql}^{-1}-200 \mu \mathrm{Eq}^{-1}$. Sites

6 with the highest variability (see standard deviations in Table 4) were also those at the

7 highest altitudes, draining the exposed meta-sediments (S 8, S 9 and S 11). In contrast, the

8 sites with lower alkalinities tended to have lower variability, with standard deviations of

$920 \mu \mathrm{Eql}^{-1}$. EC (Figure 5e) partly reflected the patterns of the alkalinity with the highest

10 alkalinities also having high EC. Nevertheless, in the valley bottom, spring and seepages EC

11 in the north (S 15, S 16 and S 17) were also high, and slightly higher than bedrock seepages

12 at S 8, S 9 and S 11 on the upper hillslopes (Table 4 and Figure 5e).

\subsection{Groundwater isoscapes}

15 The tracer data were used to map out the likely spatial variation in groundwater 16 composition at the piezometric surface where springs/seeps exfiltrated or from the wells

17 which taped the upper few metres of the saturated zone (Figures $6-8$ ). To evaluate the 18 spatial predictions using the IDW method, we calculated the mean prediction error (MPE)

19 based on a leave-one-out cross validation (loocv) for each sampling (Table 5). The MPE

20 values indicating the discrepancy between predicted and observed values were small for all 21 dates and tracers. 
1 Looking at the results of the spatial interpolation of the tracer signals across the whole

2 catchment, the groundwater isotopic composition was remarkably consistent in space

3 (Figure 6) with an average always around $-60 \%$ for $\delta^{2} \mathrm{H}$ and an overall range of $\sim 6 \%$

4 (results for $\delta^{18} \mathrm{O}$ were similar but are not shown here). The "snapshots" of the six synoptic

5 surveys also give an insight into the temporal variation of this pattern. The inset plots at

6 each sampling date in Figure 6 show the antecedent wetness conditions. What is most

7 striking is the remarkable persistence of the general spatial pattern. The first survey on the

$8 \quad 1^{\text {st }}$ October 2014 followed a relatively dry spell and the groundwater at almost all sites had

$9 \delta^{2} \mathrm{H}$-values lower than $-60 \%$ with only S 8 and S 15 being more enriched A broadly similar

10 situation was evident on $9^{\text {th }}$ April 2015, though here, only S 11 and S 19 were at $>-60 \%$.

11 The third survey in June 2015 showed a less variable picture with all sample locations

12 exhibiting $\delta^{2} \mathrm{H}$-values below $-60 \%$, despite $30 \mathrm{~mm}$ of precipitation in the previous two

13 weeks. Two months later at the end of July, following $>50 \mathrm{~mm}$ of precipitation in the

14 previous two weeks, some of the higher altitude springs (S 9, S 10 and S 11) showed slight

15 enrichment following the isotopically heavier summer precipitation (Figure 3d), as did S 15

16 and S 19 in the valley bottom. The most obvious, but still relatively small change was for the

$178^{\text {th }}$ January 2016 survey following the large precipitation input in late December 2015 and

18 early January 2016, which had a 14 day antecedent precipitation of $233 \mathrm{~mm}$. Many sample

19 sites showed more enriched groundwater (though generally $\delta^{2} \mathrm{H}$ was still in the range of -57

20 to $-59 \%$ ) which is consistent with the unusually enriched nature of this winter precipitation

21 reflecting the mild winter weather and southerly sources of the frontal systems (Figure 3d).

22 However, by the last survey in July 2016 , almost all sites were again <-60 \%o, despite almost

$2340 \mathrm{~mm}$ of precipitation in the previous two weeks. 
1 The maps of the spatially interpolated Ic-excess (Figure 7) essentially showed that

2 groundwater across the catchment had limited variation throughout the study period

3 showing little indication of evaporation fractionation (i.e. negative values) at any sites, even

4 during summer months. Even sites with higher $\delta^{2} \mathrm{H}$ levels had relatively high and positive lc-

5 excess. The lc-excess values in 2016 were most evenly distributed across the catchment and

6 generally higher compared to the sampling in 2014 and 2015. In June 2015, samples at all

7 sites were closest to zero. The high altitude springs and at the base of the scree in the

8 northern part of the valley bottom, showed highest Ic-excess values despite sometime

9 having the most enriched $\delta^{2} H$.

11 The alkalinity values were analysed at five sampling dates (insufficient sample was collected

12 in the first survey), and generally ranged between $80-200 \mu \mathrm{Eq}^{-1}$ (Figure 8). The higher

13 altitude springs in the south-western part of the catchment (S 8, S 9 and S 11) displayed the

14 highest alkalinities at multiple sampling occasions. The alkalinities generally reflected the

15 geology of the underlying bedrock type, particular in drier periods. In wetter periods, and

16 especially during the sampling on the $8^{\text {th }}$ January 2016 , this geology signal became much

17 weaker as high precipitation inputs likely decreased residence times and reduced

18 concentrations even in the most base-rich parts of the catchment.

20 5. Discussion

\section{$21 \quad 5.1$ Dynamics in groundwater hydrometrics}

22 On the steeper slopes, water table depths at sites like the DW 4 well can vary, depending on 23 antecedent wetness, from $<1.2 \mathrm{~m}$ below the surface during prolonged dry conditions, to 
1 being at the soil surface in the wettest events (Tetzlaff et al., 2014). It is probable that this

2 response is driven both by vertical recharge, as well as inflows from upslope areas where

3 the shallow ranker soils have limited storage (Fragalà and Parkin, 2010; Mueller et al., 2014).

4 In periods of extreme wetness, like in December 2015 and January 2016, overland flow

5 and/or shallow lateral subsurface storm flow may occur when the surface soil horizons

6 saturate and the hillslopes become hydrologically connected to the stream channel network

7 (Devito et al., 1996; Tromp-van Meerveld and McDonnell, 2006; Tunaley et al., 2016). In

8 contrast, during drier periods with lower water tables, groundwater seepage routes water

9 slowly downslope towards the valley bottom, this is then partitioned with some exfiltrating

10 at the edge of the saturated area and some draining deeper into the drift, much of which

11 eventually discharges to the stream (Haria and Shand, 2006; Blumstock et al., 2016;

12 Masaoka et al., 2016; Ala-aho et al., 2017).

14 On the lower footslopes, which receive this continuous seepage from the steeper upslope 15 area, peaty gley soils predominate and the water table is generally within $20 \mathrm{~cm}$ of the soil 16 surface. In wetter periods, the exfiltration of shallow groundwater at the break in slope 17 contributed to saturation of the soils at DW 3. However, deeper groundwater flows through 18 the thicker layers of the drift move towards the stream in confined conditions beneath the 19 peat. The response of the deeper flow paths to increased water levels on the steeper 20 hillslopes drives the artesian conditions (Hornberger et al., 1998; Todd and Mays, 2005)

21 observed in DW 1 particularly, but also DW 2 in wetter periods. In the upper slope, 22 groundwater levels usually peak a few hours after the stream in contrast to the valley 23 bottom, which peaks a few hours prior to the stream, with its water table usually residing 24 less than $20 \mathrm{~cm}$ below the surface (Tetzlaff et al., 2014). These differences in response times 
1 and increase in peak-to-peak lag times are not uncommon between the indiviual sections of

2 a hillslope. Haught and Van Meerveld (2011) reported an increase in peak-to-peak lag time

3 with increasing distance to the stream. This is similar to Seibert et al. (2003), who found a

4 distinct decrease in correlation between groundwater level and runoff with increasing

5 distance.

6

$7 \quad 5.2$ Stable isotopes and isoscapes

8 Given the size of the catchment, the hydrogeological heterogeneity and the diversity of flow

9 paths, the sampled groundwater showed remarkable consistency in its isotopic composition

10 in both space and time. Previous work in the catchment has shown that the high organic

11 content of the upper horizons of the catchment soils results in high water contents

12 facilitating immediate mixing and damping of the isotope signal in precipitation (Sprenger et

13 al., 2017). By depths of $50 \mathrm{~cm}$ in the profile, any isotopic variability is already considerably

14 damped (Geris et al., 2015). Indeed, Tetzlaff et al. (2014) showed that due to mixing

15 processes in the podzolic soils, the isotopic variability of precipitation was reduced by a

16 factor of 10 by the time water drained the base of the soil profile. The subsequent reduction

17 in variability in groundwater was only by a factor of 2. Thus, on the steeper upper hillslopes,

18 mixing of precipitation with resident soil water seems further enhanced by mixing in the

19 unsaturated drift giving a fairly constant isotopic composition by the time water reaches the

20 groundwater table. Such a temporal consistency in the isotopic groundwater composition

21 has been observed elsewhere in studies (e.g. Krabbenhoft et al., 1990; Yeh et al., 2009;

22 Penna et al., 2013; Thomas et al., 2013). 
1 As groundwater moves downslope from recharge to discharge areas, the composition shows

2 little change, whether exfiltrating from the upper hillslopes, lower hillslopes or even water

3 sampled from the deeper wells in the valley bottoms. Although there was some evidence of

4 the influence of recent precipitation, especially on the $8^{\text {th }}$ January 2016 sampling, the

5 isotopic composition changed little (Table 4) given the extremely large volumes of

6 precipitation input. The Ic-excess values suggest that the groundwater is most strongly

7 affected by winter recharge, which is consistent with the isotopic values. The low values in

8 DW 1 and DW 4 particularly show this. In DW 3 and, to a lesser extent, DW 2 the slightly

9 enriched isotopic values may suggest some recharge in the lower/mid slopes where podzolic

10 soils on moraines give locally elevated and freely draining areas within the more peaty soils

11 (Figure 1c). Nevertheless, the other seepages suggest an isotopically well mixed

12 groundwater source at the catchment scale despite the drainage downslope and

13 hydrogeological heterogeneities (Darling et al., 2003). This is also broadly consistent with

14 the temperature data.

16 To date isoscapes have generally been used to investigate and detect spatial patterns across

17 larger geographical scales than a headwater catchment (Darling et al., 2003; Bowen et al., 18 2009; Wassenaar et al., 2009; West et al., 2014; Katsuyama et al., 2015; Sánchez-Murillo 19 and Birkel, 2016). Nevertheless, in this study the isoscapes revealed a remarkable persistent 20 spatial pattern in stable isotopes distribution despite contrasting wetness conditions for a 21 hydrogeologically heterogeneous study site. Additionally, the isoscapes also showed that 22 the groundwater throughout the catchment is seemingly unaffected by evaporation 23 fractionation. 


\section{$1 \quad 5.3$ Water sources and relative ages}

2 The lack of variability in groundwater stable water isotopes probably reflects their limitation

3 as tracers once water ages reach around 4 years and mixing removes any signals from input

4 data (Benettin et al., 2017). Nevertheless, the greater variability of isotopes in the springs

5 and seeps draining the drift-free outcrops in the upper catchments probably indicates

6 younger waters compared to the larger water stores in the deeper drifts. This is also

7 supported by the alkalinity data. The baseflow alkalinities for the Bruntland Burn stream are

8 around $600 \mu \mathrm{Eql}^{-1}$ (Soulsby et al., 2007). This is generally higher than observed in any of the

9 seeps or springs and most likely reflects the role of deeper water entering in the stream

10 channel (Haria and Shand, 2004; Ockenden et al., 2014). Unfortunately, the bentonite

11 contamination of DW 1 and DW 2 prevented this being corroborated, but it is consistent

12 with synoptic surveys of baseflow along the channel network of the Bruntland Burn

13 (Blumstock et al., 2015).

15 This deeper groundwater makes a small, but significant contribution to stream flow 16 (perhaps 10 - 15\%, Ala-aho et al., 2017). This older water has not been directly dated, but 17 modelling studies indicate that mean ages of 3 - 5 years are likely (Soulsby et al., 2015;

18 Benettin et al., 2017). Most of the time, the stream concentrations vary between $<50 \mu \mathrm{EqI}^{-1}$

19 at high flows, when soil water runoff sources dominate, to around $200 \mu \mathrm{Eql}^{-1}$, which can be

20 viewed as a mix of groundwater and soil water (Lessels et al., 2016). In wetter conditions,

21 the alkalinity of the springs and seeps is reduced, especially in the drift-free areas, implying

22 an increased influence of younger water with reduced contact time with the solid geology.

23 This progressive dilution of weathering solute concentrations in streams during larger

24 precipitation events has been reported elsewhere (Neal et al., 1997; Shanley et al., 2002; 
1 Haria and Shand, 2004). The sites where this can be observed in the Bruntland Burn often

2 coincided with those of more variable isotope composition, reinforcing a hypothesis

3 inferring younger water sources. This difference in isotopes and variability of other solutes

4 has potential for application in coupled flow-tracer models that can be used to test such

5 hypotheses (e.g. Ala-aho et al., 2017; van Huijgevoort et al., 2016).

6

76 Conclusion

8 We integrated focused monitoring of water table dynamics and spatially distributed

9 assessment of the isotopic composition of groundwater in a Scottish Highland catchment.

10 This showed a well-mixed shallow groundwater system which exhibits limited spatial and

11 temporal variability in isotope composition. In broad terms, the groundwater system is

12 mainly recharged by winter precipitation and shows no evidence of evaporative

13 fractionation. Freely draining soils in the higher elevations of the catchment play a key role

14 in recharge which drains into shallow drift aquifers on the steeper hillslopes and deeper

15 confined aquifers in the valley bottom. The saturated nature of the drift means that

16 groundwater exfiltration is common sustaining waterlogged peaty soils in the valley bottom.

17 Our study emphasises the critical role of groundwater in upland catchments and provides

18 tracer data that can help constrain quantitative groundwater models.

\section{Acknowledgements}

21 We would like to thank the European Research Council (ERC, project GA 335910 VeWa) for funding.

22 We further thank Jonathan Dick for running the isotope analysis. 


\section{REFERENCES}

2 Aishlin P, McNamara JP. 2011. Bedrock infiltration and mountain block recharge accounting using

3

4

5

6

7 chloride mass balance. Hydrological Processes 25 (12): 1934-1948 DOI: 10.1002/hyp.7950

Ala-aho P, Soulsby C, Wang H, Tetzlaff D. 2017. Integrated surface-subsurface model to investigate the role of groundwater in headwater catchment runoff generation: A minimalist approach to parameterisation. Journal of Hydrology 547: 664-677 DOI: 10.1016/j.jhydrol.2017.02.023

Arlot S, Celisse A. 2010. A survey of cross-validation procedures for model selection. Statistics Surveys 4: 40-79 DOI: 10.1214/09-SS054

Barthold FK, Tyralla C, Schneider K, Vaché KB, Frede H-G, Breuer L. 2011. How many tracers do we need for end member mixing analysis (EMMA)? A sensitivity analysis. Water Resources Research 47 (8) DOI: 10.1029/2011WR010604

Batlle-Aguilar J, Harrington G a., Leblanc M, Welch C, Cook PG. 2014. Chemistry of groundwater discharge inferred from longitudinal river sampling. Water Resources Research 50 (2): 15501568 DOI: 10.1002/2013WR013591

Benettin P, Soulsby C, Birkel C, Tetzlaff D, Botter G, Rinaldo A. 2017. Using SAS functions and highresolution isotope data to unravel travel time distributions in headwater catchments. Water Resources Research 53 (3): 1864-1878 DOI: 10.1002/2016WR020117

Birkel C, Soulsby C, Tetzlaff D. 2011a. Modelling catchment-scale water storage dynamics: reconciling dynamic storage with tracer-inferred passive storage. Hydrological Processes $\mathbf{2 5}$ (25): 3924-3936 DOI: 10.1002/hyp.8201

Birkel C, Tetzlaff D, Dunn SM, Soulsby C. 2010. Towards a simple dynamic process conceptualization in rainfall-runoff models using multi-criteria calibration and tracers in temperate, upland catchments. Hydrological Processes 24 (3) DOI: 10.1002/hyp.7478

Birkel C, Tetzlaff D, Dunn SM, Soulsby C. 2011b. Using time domain and geographic source tracers to conceptualize streamflow generation processes in lumped rainfall-runoff models. Water Resources Research 47 (2) DOI: 10.1029/2010WR009547

Blumstock M, Tetzlaff D, Dick JJ, Nuetzmann G, Soulsby C. 2016. Spatial organization of groundwater dynamics and streamflow response from different hydropedological units in a montane catchment. Hydrological Processes 30 (21): 3735-3753 DOI: 10.1002/hyp.10848

Blumstock M, Tetzlaff D, Malcolm IA, Nuetzmann G, Soulsby C. 2015. Baseflow dynamics: Multitracer surveys to assess variable groundwater contributions to montane streams under low flows. Journal of Hydrology 527: 1021-1033 DOI: 10.1016/j.jhydrol.2015.05.019

Bowen GJ, West JB. 2008. Isotope Landscapes for Terrestrial Migration Research. In Terrestrial Ecology79-105. DOI: 10.1016/S1936-7961(07)00004-8 
Bowen GJ, West JB, Hoogewerff J. 2009. Isoscapes: Isotope mapping and its applications. Journal of 2 Geochemical Exploration 102 (3): v-vii DOI: 10.1016/j.gexplo.2009.05.001

Craig H, Gordon LI, Horibe Y. 1963. Isotopic exchange effects in the evaporation of water: 1. Lowtemperature experimental results. Journal of Geophysical Research 68 (17): 5079-5087 DOI: 10.1029/JZO68i017p05079

Dansgaard W. 1964. Stable isotopes in precipitation. Tellus 16 (4): 436-468 DOI: 10.3402/tellusa.v16i4.8993

Darling WG, Bath AH, Talbot JC. 2003. The O \& H stable isotopic composition of fresh waters in the British Isles . 2 . Surface waters and groundwater. Hydrology and Earth System Sciences 7 (2): 183-195

Devito KJ, Hill AR, Roulet N. 1996. Groundwater-surface water interactions in headwater forested wetlands of the Canadian Shield. Journal of Hydrology 181 (1-4): 127-147 DOI: 10.1016/00221694(95)02912-5

Fragalà FA, Parkin G. 2010. Local recharge processes in glacial and alluvial deposits of a temperate catchment. Journal of Hydrology 389 (1-2): 90-100 DOI: 10.1016/j.jhydrol.2010.05.025

Frisbee MD, Phillips FM, Campbell AR, Liu F, Sanchez SA. 2011. Streamflow generation in a large, alpine watershed in the southern Rocky Mountains of Colorado: Is streamflow generation simply the aggregation of hillslope runoff responses? Water Resources Research 47 (6) DOI: 10.1029/2010WR009391

Gabrielli CP, McDonnell JJ. 2012. An inexpensive and portable drill rig for bedrock groundwater studies in headwater catchments. Hydrological Processes 26 (4): 622-632 DOI: 10.1002/hyp.8212

Geris J, Tetzlaff D, McDonnell JJ, Soulsby C. 2015. The relative role of soil type and tree cover on water storage and transmission in northern headwater catchments. Hydrological Processes 29 (7): 1844-1860 DOI: 10.1002/hyp.10289

Gleeson T, Wada Y, Bierkens MFP, van Beek LPH. 2012. Water balance of global aquifers revealed by groundwater footprint. Nature 488 (7410): 197-200 DOI: 10.1038/nature11295

Haria AH, Shand P. 2004. Evidence for deep sub-surface flow routing in forested upland Wales: implications for contaminant transport and stream flow generation. Hydrology and Earth System Sciences 8 (3): 334-344 DOI: 10.5194/hess-8-334-2004

Haria AH, Shand P. 2006. Near-stream soil water-groundwater coupling in the headwaters of the Afon Hafren, Wales: Implications for surface water quality. Journal of Hydrology 331 (3-4): 567-579 DOI: 10.1016/j.jhydrol.2006.06.004

Haught DRW, Van Meerveld HJ. 2011. Spatial variation in transient water table responses: 
Differences between an upper and lower hillslope zone. Hydrological Processes $\mathbf{2 5}$ (November):

2

3

4

5

6

7

8

9

10

11

12

13

14

15

16

17

18

19

20

21

22

23

24

25

26

27

28

29

30

31

32

33

34

3866-3877 DOI: 10.1002/hyp.8354

Hornberger GM, Raffensperger JP, Wiberg PL, Eshleman KN. 1998. 6.4 Water in Natural Formations. In Elements of Physical HydrologyJohns Hopkins University Press; 155-159.

Jasechko S, Kirchner JW, Welker JM, McDonnell JJ. 2016. Substantial proportion of global streamflow less than three months old. Nature Geoscience 9 (2): 126-129 DOI: 10.1038/ngeo2636

Katsuyama M, Yoshioka T, Konohira E. 2015. Spatial distribution of oxygen-18 and deuterium in stream waters across the Japanese archipelago. Hydrology and Earth System Sciences 19 (3): 1577-1588 DOI: 10.5194/hess-19-1577-2015

Kendall C, McDonnell JJ. 1998. Isotope Tracers in Catchment Hydrology. Elsevier sciene: Amsterdam. Krabbenhoft DP, Bowser CJ, Anderson MP, Valley JW. 1990. Estimating groundwater exchange with lakes: 1. The stable isotope mass balance method. Water Resources Research 26 (10): 24452453 DOI: 10.1029/WR026i010p02445

Landwehr JM, Coplen TB. 2006. Line-conditioned excess: a new method for characterizing stable hydrogen and oxygen isotope ratios in hydrologic systems. In Isotopes in Environmental Studies - Aquatic Forum 2004IAEA; 132-135.

Leibundgut C, Maloszewski P, Külls C. 2009. Tracers in Hydrology. John Wiley \& Sons.

Lessels JS, Tetzlaff D, Birkel C, Dick JJ, Soulsby C. 2016. Water sources and mixing in riparian wetlands revealed by tracers and geospatial analysis. Water Resources Research 52 (1): 456-470 DOI: 10.1002/2015WR017519

Marsh TJ, Kirby C, Barker L, Henderson E, Hannaford J. 2016. The winter floods of 2015 / 2016 in the UK - a review.

Masaoka N, Kosugi K, Yamakawa Y, Tsutsumi D. 2016. Processes of bedrock groundwater seepage and their effects on soil water fluxes in a foot slope area. Journal of Hydrology 535: 160-172 DOI: 10.1016/j.jhydrol.2016.01.081

Mueller MH, Alaoui A, Kuells C, Leistert H, Meusburger K, Stumpp C, Weiler M, Alewell C. 2014. Tracking water pathways in steep hillslopes by $\delta 180$ depth profiles of soil water. Journal of Hydrology 519: 340-352 DOI: 10.1016/j.jhydrol.2014.07.031

Neal C. 2001. Alkalinity measurements within natural waters: towards a standardised approach. Science of The Total Environment 265 (1-3): 99-113 DOI: 10.1016/S0048-9697(00)00652-5

Neal C, Hill T, Hill S, Reynolds B. 1997. Acid neutralization capacity measurements in surface and ground waters in the Upper River Severn, Plynlimon: from hydrograph splitting to water flow pathways. Hydrology and Earth System Sciences 1 (3): 687-696 DOI: 10.5194/hess-1-687-1997

Ockenden MC, Chappell N a., Neal C. 2014. Quantifying the differential contributions of deep 
groundwater to streamflow in nested basins, using both water quality characteristics and water balance. Hydrology Research 45 (2): 200 DOI: 10.2166/nh.2013.035

Penna D, Oliviero O, Assendelft R, Zuecco G, van Meerveld IHJ, Anfodillo T, Carraro V, Borga M, Fontana GD. 2013. Tracing the Water Sources of Trees and Streams: Isotopic Analysis in a Small

Pre-Alpine Catchment. Procedia Environmental Sciences 19 (March): 106-112 DOI:

$$
\text { 10.1016/j.proenv.2013.06.012 }
$$

Raidla V, Kern Z, Pärn J, Babre A, Erg K, Ivask J, Kalvāns A, Kohán B, Lelgus M, Martma T, Mokrik R, Popovs K, Vaikmäe R. 2016. A $\delta 18$ O isoscape for the shallow groundwater in the Baltic Artesian Basin. Journal of Hydrology 542: 254-267 DOI: 10.1016/j.jhydrol.2016.09.004

Sánchez-Murillo R, Birkel C. 2016. Groundwater recharge mechanisms inferred from isoscapes in a complex tropical mountainous region. Geophysical Research Letters 43 (10): 5060-5069 DOI: 10.1002/2016GL068888

Šanda M, Vitvar T, Kulasová A, Jankovec J, Císlerová M. 2014. Run-off formation in a humid, temperate headwater catchment using a combined hydrological, hydrochemical and isotopic approach (Jizera Mountains, Czech Republic). Hydrological Processes 28 (8): 3217-3229 DOI: 10.1002/hyp.9847

Seibert J, Bishop K, Rodhe A, McDonnell JJ. 2003. Groundwater dynamics along a hillslope: A test of the steady state hypothesis. Water Resources Research 39 (1) DOI: 10.1029/2002WR001404

Shanley JB, Kendall C, Smith TE, Wolock DM, McDonnell JJ. 2002. Controls on old and new water contributions to stream flow at some nested catchments in Vermont, USA. Hydrological Processes 16 (3): 589-609 DOI: 10.1002/hyp.312

Soulsby C, Birkel C, Geris J, Dick JJ, Tunaley C, Tetzlaff D. 2015. Stream water age distributions controlled by storage dynamics and nonlinear hydrologic connectivity: Modeling with highresolution isotope data. Water Resources Research 51 (9): 7759-7776 DOI: 10.1002/2015WR017888

Soulsby C, Bradford J, Dick JJ, P. McNamara J, Geris J, Lessels JS, Blumstock M, Tetzlaff D. 2016. Using geophysical surveys to test tracer-based storage estimates in headwater catchments. Hydrological Processes (April) DOI: 10.1002/hyp.10889

Soulsby C, Chen M, Ferrier RC, Helliwell RC, Jenkins A, Harriman R. 1998. Hydrogeochemistry of shallow groundwater in an upland Scottish catchment. Hydrological Processes 12 (7): 11111127 DOI: 10.1002/(SICI)1099-1085(19980615)12:7<1111::AID-HYP633>3.0.CO;2-2

Soulsby C, Dick JJ, Scheliga B, Tetzlaff D. 2017. Taming the Flood - how far can we go with trees? Hydrological Processes DOI: 10.1002/HYP.11226

Soulsby C, Malcolm R, Helliwell R, Ferrier RC, Jenkins A. 2000. Isotope hydrology of the Allt a' 
Mharcaidh catchment, Cairngorms, Scotland: implications for hydrological pathways and residence times. Hydrological Processes 14 (4): 747-762 DOI: 10.1002/(SICI)10991085(200003)14:4<747::AID-HYP970>3.0.CO;2-0

Soulsby C, Malcolm IA, Youngson AF, Tetzlaff D, Gibbins CN, Hannah DM. 2005. Groundwater-surface 5 water interactions in upland Scottish rivers: hydrological, hydrochemical and ecological implications. Scottish Journal of Geology 41 (1): 39-49 DOI: 10.1144/sjg41010039

Soulsby C, Rodgers P, Petry J, Hannah DM, Malcolm IA, Dunn SM. 2004. Using tracers to upscale flow 8 path understanding in mesoscale mountainous catchments: Two examples from Scotland. Journal of Hydrology 291 (3-4): 174-196 DOI: 10.1016/j.jhydrol.2003.12.042

Soulsby C, Tetzlaff D, van den Bedem N, Malcolm IA, Bacon PJ, Youngson AF. 2007. Inferring groundwater influences on surface water in montane catchments from hydrochemical surveys of springs and streamwaters. Journal of Hydrology 333 (2-4): 199-213 DOI: 10.1016/j.jhydrol.2006.08.016

Sprenger M, Tetzlaff D, Tunaley C, Dick JJ, Soulsby C. 2017. Evaporation fractionation in a peatland drainage network affects stream water isotope composition. Water Resources Research 53 (1): 851-866 DOI: 10.1002/2016WR019258

Tetzlaff D, Soulsby C. 2008. Sources of baseflow in larger catchments - Using tracers to develop a holistic understanding of runoff generation. Journal of Hydrology 359 (3-4): 287-302 DOI: 10.1016/j.jhydrol.2008.07.008

Tetzlaff D, Birkel C, Dick JJ, Geris J, Soulsby C. 2014. Storage dynamics in hydropedological units control hillslope connectivity, runoff generation, and the evolution of catchment transit time distributions. Water Resources Research 50 (2): 969-985 DOI: 10.1002/2013WR014147

Tetzlaff D, Capell R, Soulsby C. 2012. Land use and hydroclimatic influences on Faecal Indicator Organisms in two large Scottish catchments: Towards land use-based models as screening tools. Science of The Total Environment 434: 110-122 DOI: 10.1016/j.scitotenv.2011.11.090

Tetzlaff D, Soulsby C, Waldron S, Malcolm IA, Bacon PJ, Dunn SM, Lilly A, Youngson AF. 2007. Conceptualization of runoff processes using a geographical information system and tracers in a nested mesoscale catchment. Hydrological Processes 21 (10): 1289-1307 DOI: 10.1002/hyp.6309

Thomas EM, Lin H, Duffy CJ, Sullivan PL, Holmes GH, Brantley SL, Jin L. 2013. Spatiotemporal Patterns of Water Stable Isotope Compositions at the Shale Hills Critical Zone Observatory: Linkages to Subsurface Hydrologic Processes. Vadose Zone Journal 12 (4) DOI: 10.2136/vzj2013.01.0029 Todd DK, Mays LW. 2005. Groundwater hydrology (B Zobrist, J Welter, and VA Vargas, eds). John Wiley \& Sons, Inc. 
1 Tromp-van Meerveld HJ, McDonnell JJ. 2006. Threshold relations in subsurface stormflow: 1. A 147-

2 storm analysis of the Panola hillslope. Water Resources Research 42 (2): 1-11 DOI:

$3 \quad 10.1029 / 2004$ WR003778

4 Tunaley C, Tetzlaff D, Lessels JS, Soulsby C. 2016. Linking high-frequency DOC dynamics to the age of $5 \quad$ connected water sources. Water Resources Research 52 (7): 5232-5247 DOI: 10.1002/2015WR018419

7 Wassenaar LI, Van Wilgenburg SL, Larson K, Hobson KA. 2009. A groundwater isoscape (סD, $\delta 180)$

$9 \quad$ 10.1016/j.gexplo.2009.01.001

10 West AG, February EC, Bowen GJ. 2014. Spatial analysis of hydrogen and oxygen stable isotopes

11 ('isoscapes') in ground water and tap water across South Africa. Journal of Geochemical

12 Exploration 145: 213-222 DOI: 10.1016/j.gexplo.2014.06.009

13 Yeh H, Lee C, Hsu K, Chang P, Wang C. 2009. Using Stable Isotopes for Assessing the Hydrologic 14 Characteristics and Sources of Groundwater Recharge. J. Environ. Eng. Manage. 19 (4): 185191 
Table 1: Characteristics of the monitored groundwater wells

\begin{tabular}{lc|c|c|c|c} 
ID & & DW 1 & DW 2 & DW 3 & DW 4 \\
\hline Depth & {$[\mathrm{cm}]$} & 330 & 264 & 160 & 187 \\
Distance to Stream & {$[\mathrm{m}]$} & 7 & 20 & 122 & 339 \\
Distance to Outlet & {$[\mathrm{m}]$} & 767 & 785 & 835 & 994 \\
\hline
\end{tabular}

10

11

12

13

14

15

16

17

18

19

20

21

22

23

24

25

26

27

28

29

30

31

32

33

34

35

36

37

38

39

40

41

42

43

44

45

46

47

48

49

50

51

52

53

54

55

56

57

58

59

60

http://mc.manuscriptcentral.com/hyp 
Table 2: Landscape characteristics of the deeper wells (DW) and springs/seepages (S): elevation, topographic wetness index (TWI), slope, soil type, dominant geology and information if overlain with glacial drift cover. Elevation, Slope and TWI were derived from a high resolution LiDAR elevation model.

\begin{tabular}{l|c|c|c|l|l|l} 
ID & Elevation [m a.s.I.] & TWI & Slope $\left[^{\circ}\right.$ ] & Soil type & \multicolumn{1}{c}{ Geology } & Drift deposit \\
\hline DW 1 & 254 & 15.1 & 0.6 & Peat & Granite & yes \\
DW 2 & 254 & 15.5 & 0.6 & Peat & Granite & yes \\
DW 3 & 259 & 11.1 & 0.2 & Peaty gley & Granite & yes \\
DW 4 & 284 & 2.4 & 18.2 & Peaty podzol & Granite & yes \\
S 1 & 291 & 6.1 & 18.6 & Peaty podzol & Granite & no \\
S 2 & 308 & 4.8 & 23.4 & Brown ranker & Granite & no \\
S 3 & 336 & 3.6 & 14.4 & Peaty podzol & Si-rich metasediment & no \\
S 4 & 400 & 4.9 & 18.5 & Brown ranker & Si-rich metasediment & yes \\
S 5 & 406 & 5.9 & 18.9 & Peaty podzol & Si-rich metasediment & no \\
S 6 & 424 & 6.3 & 12.4 & Peaty podzol & Ca-rich metasediment & no \\
S 7 & 428 & 8.8 & 5.8 & Peaty podzol & Si-rich metasediment & no \\
S 8 & 440 & 3.2 & 17.2 & Brown ranker & Si-rich metasediment & no \\
S 9 & 461 & 6.5 & 19.7 & Brown ranker & Si-rich metasediment & no \\
S 10 & 465 & 8.7 & 3 & Brown ranker & Granite & no \\
S 11 & 434 & 7.8 & 7.8 & Brown ranker & Si-rich metasediment & no \\
S 12 & 284 & 6.4 & 4.2 & Brown ranker & Granite & no \\
S 13 & 285 & 5.4 & 10.5 & Brown ranker & Granite & yes \\
S 14 & 270 & 7.9 & 2.4 & Peat & Granite & yes \\
S 15 & 263 & 6.6 & 5 & Peat & Granite & yes \\
S 16 & 256 & 5.7 & 4.8 & Peat & Granite & yes \\
S 17 & 255 & 8.3 & 1.4 & Peat & Granite & yes \\
S 18 & 255 & 6.5 & 8.6 & Peat & Granite & yes \\
S 19 & 253 & 5.9 & 2.3 & Peat & Granite & yes \\
S 20 & 252 & 2.7 & 15.1 & Peaty podzol & Granite & yes \\
\hline
\end{tabular}


Table 3: Summary statistics of the water tables and temperatures recorded in the deeper well (DW) (Minimum, Maximum, Mean, Median values, standard deviation, and range)

\begin{tabular}{|c|c|c|c|c|c|}
\hline ID & & DW 1 & DW 2 & DW 3 & DW 4 \\
\hline $\mathrm{GW}_{\text {level }} \mathrm{Min}_{\mathrm{M}}$ & {$[\mathrm{cm}]$} & -4.3 & -20.4 & -37.4 & -108.9 \\
\hline GW level $\mathrm{Max}_{\mathrm{M}}$ & {$[\mathrm{cm}]$} & 31.4 & 16.4 & -2.5 & 0.3 \\
\hline $\mathrm{GW}_{\text {level }} \mathrm{I}_{\text {Mean }}$ & {$[\mathrm{cm}]$} & 7.6 & -2.4 & -19.3 & -66.6 \\
\hline GW level $\left.\right|_{\text {Median }}$ & {$[\mathrm{cm}]$} & 7.9 & 0.5 & -18.4 & -76.3 \\
\hline $\mathrm{GW}_{\text {level }}$ Std.Dev. & {$[\mathrm{cm}]$} & 5.5 & 7.2 & 7.1 & 31.9 \\
\hline GW level $\left.\right|_{\text {Range }}$ & {$[\mathrm{cm}]$} & 35.6 & 36.8 & 34.9 & 109.2 \\
\hline $\mathrm{Temp}_{\text {Min }}$ & {$\left[{ }^{\circ} \mathrm{C}\right]$} & 6.7 & 6.5 & 4.3 & 4.7 \\
\hline Temp $_{\operatorname{Max}}$ & {$\left[{ }^{\circ} \mathrm{C}\right]$} & 7.8 & 8.4 & 10.3 & 9 \\
\hline Temp $_{\text {Mean }}$ & {$\left[{ }^{\circ} \mathrm{C}\right]$} & 7.3 & 7.4 & 7.3 & 7 \\
\hline Temp $_{\text {Median }}$ & {$\left[{ }^{\circ} \mathrm{C}\right]$} & 7.3 & 7.5 & 7.2 & 7 \\
\hline Temp $_{\text {Std.Dev. }}$ & {$\left[{ }^{\circ} \mathrm{C}\right]$} & 0.4 & 0.6 & 1.9 & 1.4 \\
\hline Temp $p_{\text {Range }}$ & {$\left[{ }^{\circ} \mathrm{C}\right]$} & 1.1 & 1.8 & 6 & 4.3 \\
\hline
\end{tabular}

http://mc.manuscriptcentral.com/hyp 
Table 4: Summary statistics (mean, median, standard deviation) for $\delta^{2} \mathrm{H}, \delta^{18} \mathrm{O}$, alkalinity and electrical conductivity measured in precipitation, stream water, deeper wells and springs/seepages samples over the study period. Precipitation and stream water were sampled daily, deeper wells - if possible - monthly and the springs/seepages on six different days under different wetting conditions.

\begin{tabular}{|c|c|c|c|c|c|c|c|c|c|c|c|c|c|c|c|}
\hline \multirow[b]{2}{*}{ ID } & \multicolumn{3}{|c|}{$\delta^{2} H[\% \circ]$} & \multicolumn{3}{|c|}{$\delta^{18} \mathrm{O}[\% \mathrm{o}]$} & \multicolumn{3}{|c|}{ Ic-excess [\%o] } & \multicolumn{3}{|c|}{ Alkalinity $\left[\mu \mathrm{Eq}^{-1}\right]$} & \multicolumn{3}{|c|}{$\begin{array}{l}\text { Electrical Conductivity } \\
\qquad\left[\mu \mathrm{S} \mathrm{cm}^{-1}\right]\end{array}$} \\
\hline & mean & median & $\begin{array}{l}\text { standard } \\
\text { deviation }\end{array}$ & mean & median & $\begin{array}{l}\text { standard } \\
\text { deviation }\end{array}$ & mean & median & $\begin{array}{l}\text { standard } \\
\text { deviation }\end{array}$ & mean & median & $\begin{array}{l}\text { standard } \\
\text { deviation }\end{array}$ & mean & median & $\begin{array}{l}\text { standard } \\
\text { deviation }\end{array}$ \\
\hline Precipitation & -56.4 & -55.1 & 24.2 & -7.9 & -7.5 & 3.0 & 0 & 0 & 5 & - & - & - & - & - & - \\
\hline Outlet & -57.9 & -57.5 & 2.5 & -8.4 & -8.5 & 0.4 & 3 & 3 & 1 & - & - & - & - & - & - \\
\hline DW 1 & -61.1 & -61.2 & 0.5 & -9.1 & -9.1 & 0.2 & 4 & 5 & 5 & - & - & - & - & - & - \\
\hline DW 2 & -59.1 & -59.3 & 0.8 & -8.8 & -8.8 & 0.2 & 4 & 8 & 5 & - & - & - & - & - & - \\
\hline DW 3 & -57.7 & -58.0 & 1.2 & -8.5 & -8.6 & 0.3 & 4 & 4 & 4 & - & - & - & - & - & - \\
\hline DW 4 & -62.0 & -61.5 & 1.0 & -9.2 & -9.3 & 0.3 & 4 & 5 & 5 & - & - & - & - & - & - \\
\hline S 1 & -60.9 & -61.3 & 1.2 & -9.0 & -9.1 & 0.1 & 4 & 4 & 4 & 117.4 & 118.6 & 28.3 & 43.9 & 44.0 & 5.0 \\
\hline S 2 & -61.6 & -62.5 & 2.2 & -9.1 & -9.1 & 0.3 & 3 & 6 & 4 & 86.6 & 90.2 & 16.5 & 38.2 & 40.1 & 6.8 \\
\hline S 3 & -61.1 & -61.8 & 1.6 & -8.9 & -9.0 & 0.2 & 3 & 7 & 3 & 94.1 & 102.6 & 22.6 & 38.1 & 38.2 & 4.0 \\
\hline S 4 & -60.8 & -61.1 & 1.2 & -9.0 & -9.1 & 0.4 & 4 & 6 & 4 & 102.9 & 90.6 & 20.3 & 39.5 & 40.2 & 5.6 \\
\hline S 5 & -61.0 & -61.0 & 0.7 & -9.1 & -9.1 & 0.2 & 5 & 4 & 5 & 106.3 & 111.0 & 32.6 & 40.2 & 39.3 & 11.2 \\
\hline S 6 & -59.9 & -60.1 & 1.1 & -8.8 & -9.0 & 0.3 & 4 & 5 & 4 & 139.4 & 145.2 & 21.8 & 46.3 & 43.5 & 13.4 \\
\hline S 7 & -61.6 & -61.8 & 1.6 & -9.1 & -9.2 & 0.3 & 4 & 2 & 4 & 235.7 & 240.2 & 25.4 & 54.3 & 55.6 & 7.9 \\
\hline S 8 & -60.6 & -60.6 & 1.0 & -9.0 & -9.1 & 0.2 & 5 & 4 & 5 & 252.8 & 242.1 & 61.9 & 55.5 & 54.0 & 8.8 \\
\hline S 9 & -59.7 & -59.2 & 1.5 & -9.0 & -9.0 & 0.2 & 5 & 2 & 5 & 285.6 & 319.5 & 82.0 & 65.4 & 66.1 & 15.6 \\
\hline S 10 & -59.7 & -60.2 & 2.9 & -8.7 & -8.8 & 0.6 & 3 & 5 & 3 & 83.3 & 80.1 & 22.0 & 46.6 & 40.8 & 20.6 \\
\hline S 11 & -59.5 & -60.7 & 2.4 & -8.7 & -8.7 & 0.6 & 3 & 6 & 3 & 206.3 & 213.3 & 85.3 & 68.7 & 68.0 & 13.4 \\
\hline S 12 & -61.7 & -61.6 & 0.9 & -9.0 & -9.0 & 0.1 & 4 & 2 & 4 & 117.4 & 125.4 & 45.4 & 52.3 & 51.9 & 9.8 \\
\hline S 13 & -60.9 & -60.7 & 1.2 & -9.0 & -9.0 & 0.3 & 4 & 4 & 4 & 100.5 & 92.7 & 18.1 & 50.7 & 49.7 & 6.0 \\
\hline S 14 & -60.4 & -60.7 & 0.5 & -8.8 & -8.8 & 0.1 & 3 & 2 & 3 & 122.8 & 130.4 & 25.4 & 54.5 & 54.4 & 8.5 \\
\hline S 15 & -58.8 & -59.3 & 1.4 & -8.6 & -8.7 & 0.3 & 3 & 3 & 3 & 139.8 & 147.4 & 25.7 & 78.6 & 75.8 & 20.9 \\
\hline S 16 & -60.9 & -60.9 & 0.9 & -9.0 & -9.0 & 0.2 & 4 & 6 & 4 & 151.9 & 168.8 & 40.1 & 74.5 & 75.7 & 7.9 \\
\hline S 17 & -61.0 & -60.9 & 1.3 & -9.0 & -9.0 & 0.3 & 4 & 6 & 4 & 111.5 & 108.1 & 23.4 & 73.0 & 72.5 & 6.1 \\
\hline S 18 & -60.2 & -60.5 & 1.6 & -9.0 & -9.0 & 0.1 & 4 & 2 & 5 & 95.1 & 89.2 & 28.7 & 56.6 & 54.6 & 5.8 \\
\hline S 19 & -59.5 & -59.5 & 1.0 & -8.8 & -8.6 & 0.4 & 4 & 5 & 4 & 112.1 & 112.4 & 23.4 & 62.1 & 61.4 & 9.1 \\
\hline S 20 & -61.1 & -61.0 & 1.2 & -8.9 & -8.9 & 0.1 & 3 & 3 & 3 & 95.1 & 90.3 & 27.3 & 56.2 & 55.0 & 3.6 \\
\hline
\end{tabular}


Table 5: Mean prediction error (MPE) for the inverse distance weighting interpolation from the leave-one-out cross validation (loocv) on the six different sampling dates for $\delta^{2} \mathrm{H}$, Ic-excess, alkalinity and conductivity.

\begin{tabular}{ccccc} 
& $\delta^{2} \mathrm{H}[\% \circ]$ & $\begin{array}{c}\text { Ic-excess } \\
{[\%]}\end{array}$ & $\begin{array}{c}\text { Alkalinity } \\
{\left[\left.\mu \mathrm{Eq}\right|^{-1}\right]}\end{array}$ & $\begin{array}{c}\text { Electrical Conductivity } \\
{\left[\mu \mathrm{S} \mathrm{cm}^{-1}\right]}\end{array}$ \\
\cline { 2 - 5 } Date & & & $\mathrm{MPE}$ & \\
\hline $01 / 10 / 2014$ & -0.02 & 0.28 & - & -1.36 \\
$09 / 04 / 2015$ & -0.33 & 0.14 & -2.66 & 0.29 \\
$01 / 06 / 2015$ & -0.04 & -0.02 & -3.91 & 1.56 \\
$31 / 07 / 2015$ & -0.24 & 0.05 & -3.2 & -0.89 \\
$08 / 01 / 2016$ & -0.11 & -0.06 & 1.75 & 1.75 \\
$13 / 07 / 2016$ & -0.06 & 0.01 & -4.06 & 0.77
\end{tabular}




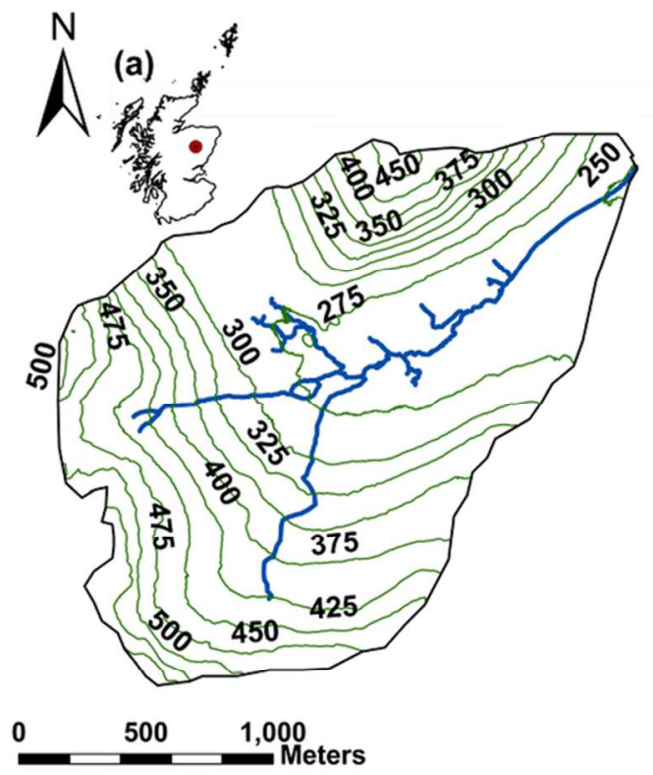

(c)

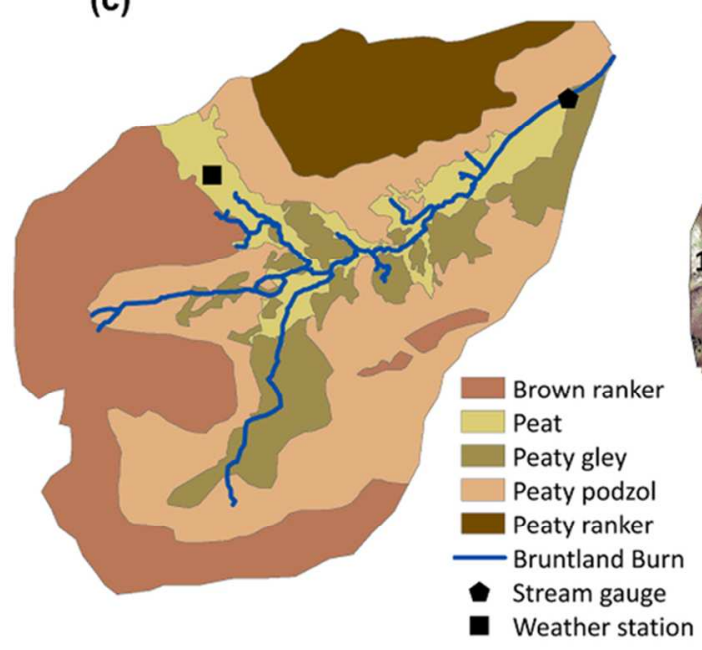

(b)

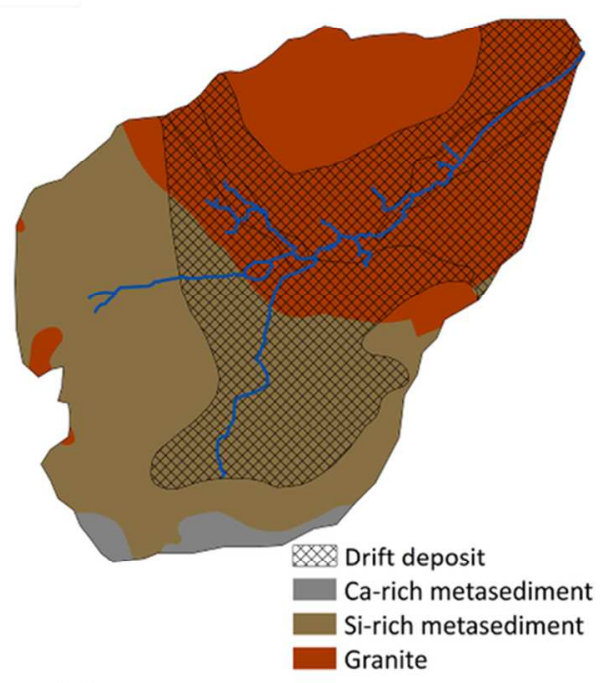

(d)

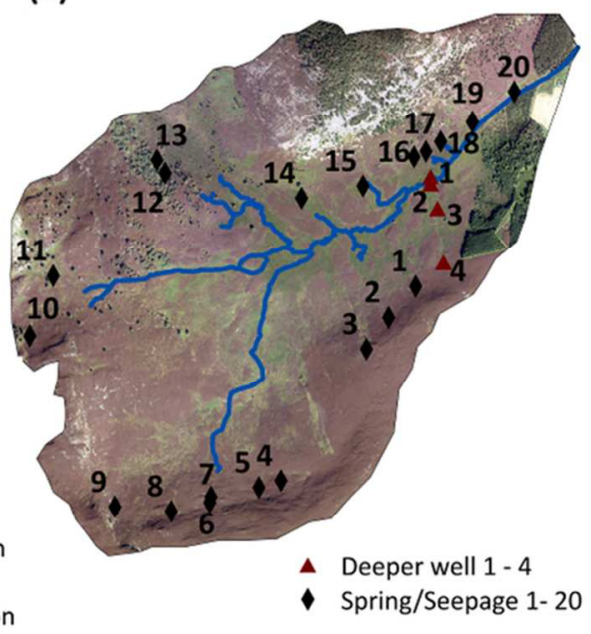

Figure 1: Bruntland Burn catchment showing (a) the topography; (b) dominant bedrock types and the extent of the overlying drift deposits; (c) dominant soil types and location of the deeper wells (DW), sampled spring/seepages (S), weather station and stream gauge; and (d) an aerial photo of the catchment including the sampled locations.

$$
41 \times 46 \mathrm{~mm}(600 \times 600 \mathrm{DPI})
$$




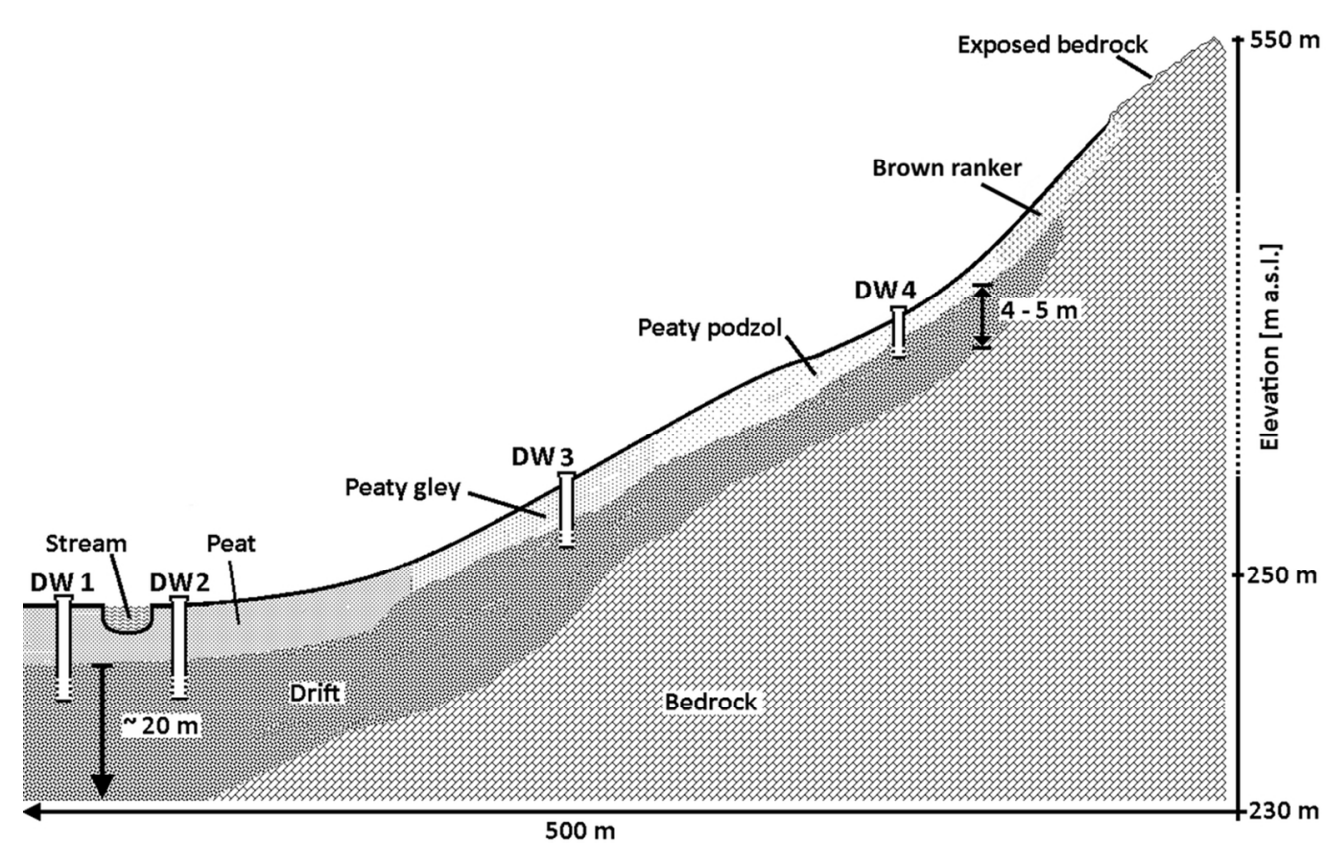

Figure 2: A generalized cross-section of a hillslope in the Bruntland Burn catchment. Diagram not to scale.

$52 \times 33 \mathrm{~mm}(600 \times 600 \mathrm{DPI})$ 


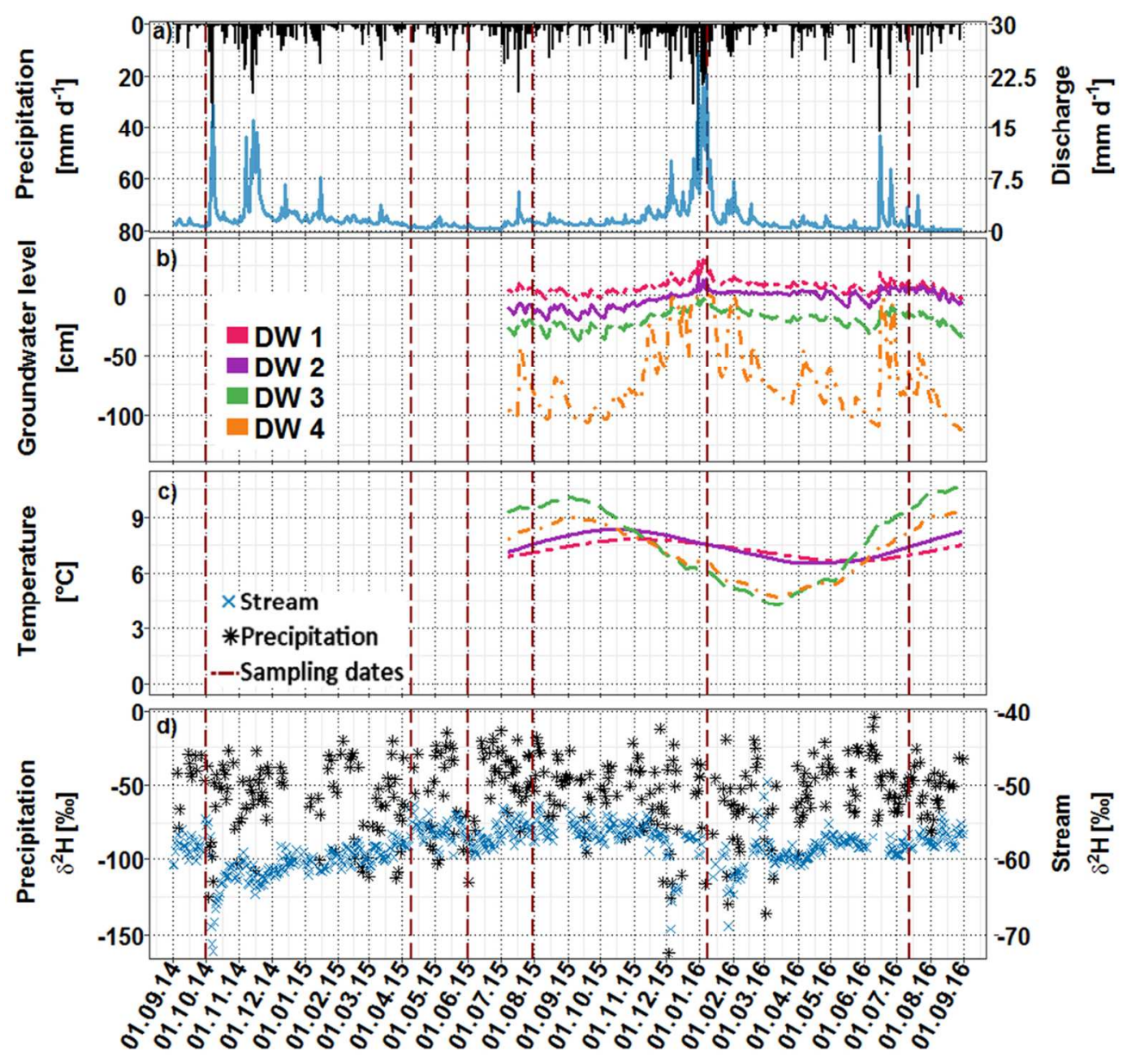

Figure 3: a) Daily precipitation and discharge at the catchment outlet, b) groundwater levels (relative to the ground surface) at the 4 deep wells, c) water temperature inside the wells and d) daily $\delta^{2} \mathrm{H}$ time series for precipitation and stream flow the study period.

\section{$59 \times 56 \mathrm{~mm}(600 \times 600 \mathrm{DPI})$}




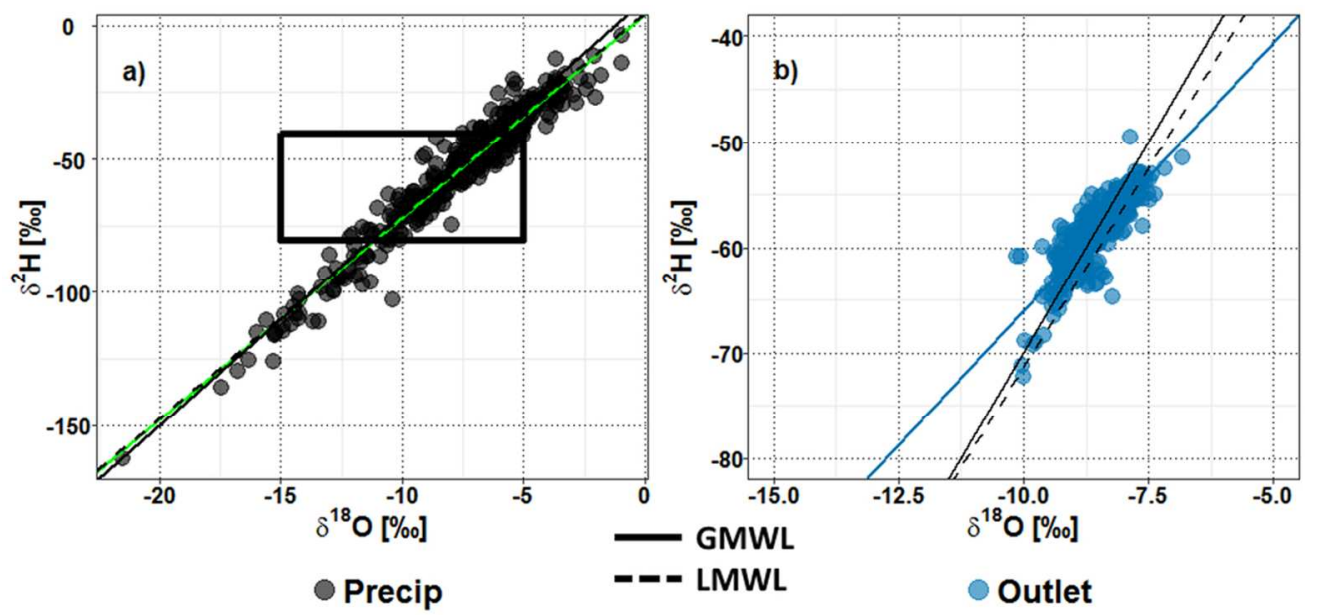

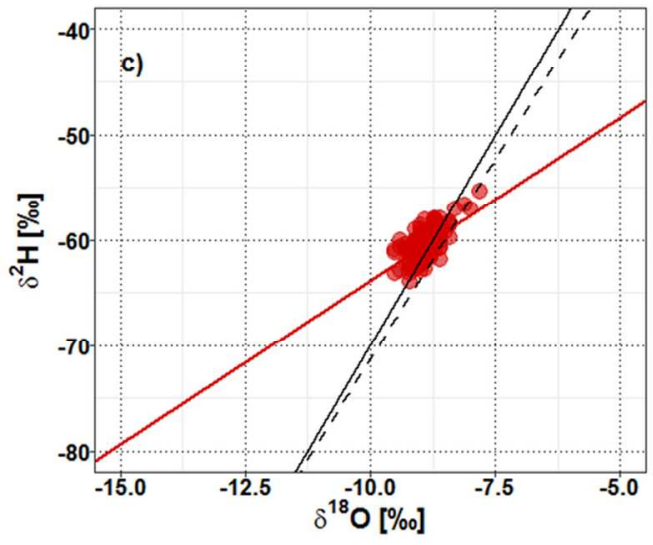

- Springs \& Seepages

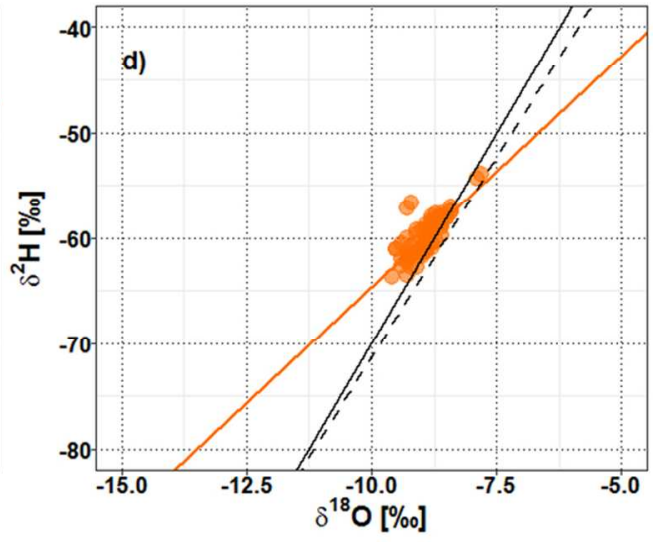

- Deeper Wells

Figure 4: Dual isotope plot of the a) precipitation with the black square indicating the area enlarger in plots b)-d), the green line is the respective regression line (slope $=7.6 \%$, intersect $=4.1 \%$, $r^{2}=0.95$ ) during the study period; b) stream water at the outlet with the respective regression line (slope $=5.1 \%$, intersect $=-15 \%, r^{2}=0.71$ ) in blue; d) deeper well samples during the study period August 2015 - May 2016 the respective regression line (slope $=4.4 \%$, intersect $=-20.6 \%, r^{2}=0.71$ ) in orange. The $\left.c\right)$ spring sample were collected on six occasions between October 2014 and July 2016; the respective regression line (slope=

$3.1 \%$, intersect $=-32.8 \%, r^{2}=0.52$ ) is red. All circles are half-transparent to emphasis overlapping values.

$50 \times 47 \mathrm{~mm}(600 \times 600 \mathrm{DPI})$ 

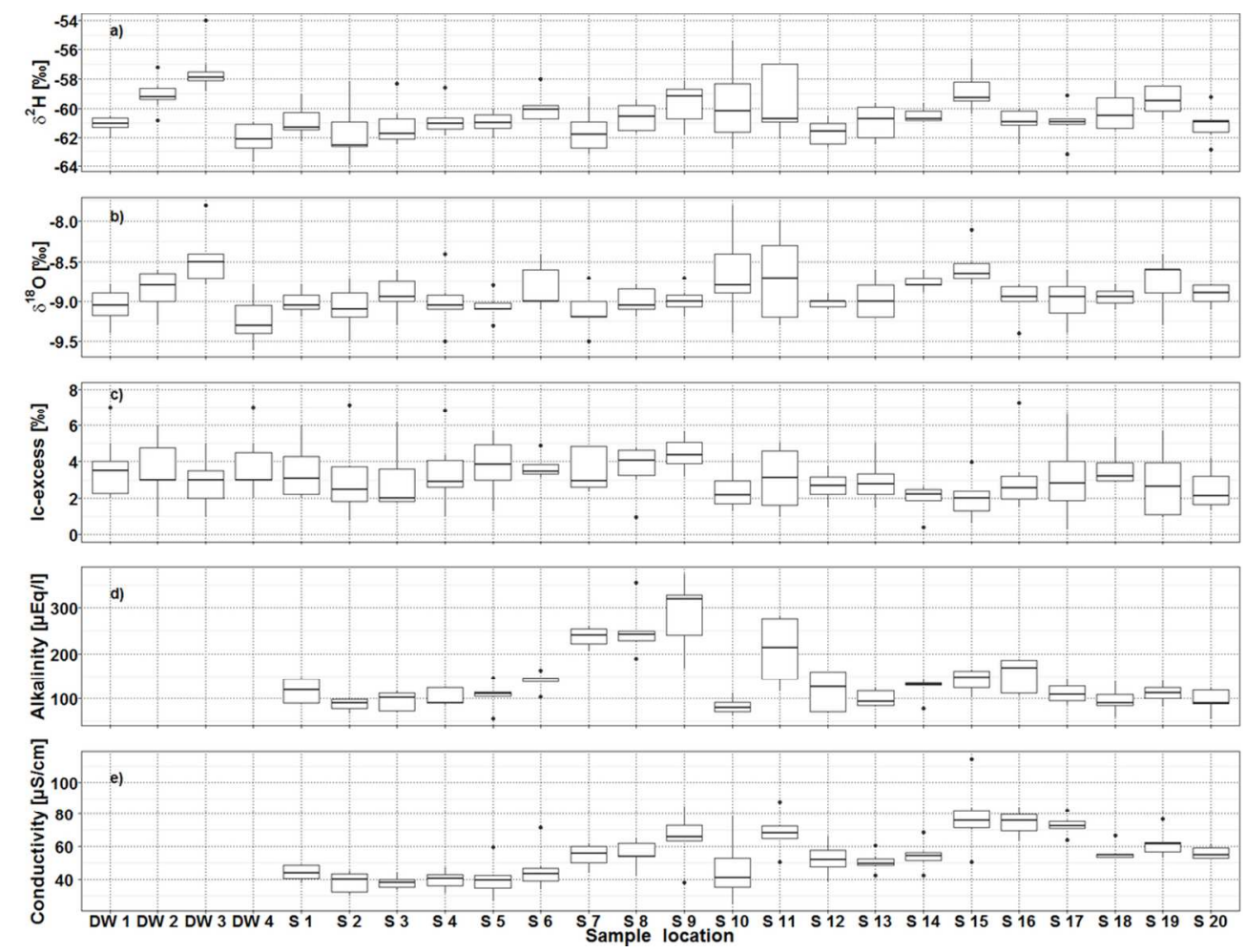

Figure 5: Boxplots for a) $\delta^{2} \mathrm{H}$; b) $\delta^{18} \mathrm{O}$; c) Ic-excess; d) alkalinity and e) conductivity for all sampling $50 \times 37 \mathrm{~mm}(600 \times 600 \mathrm{DPI})$ 


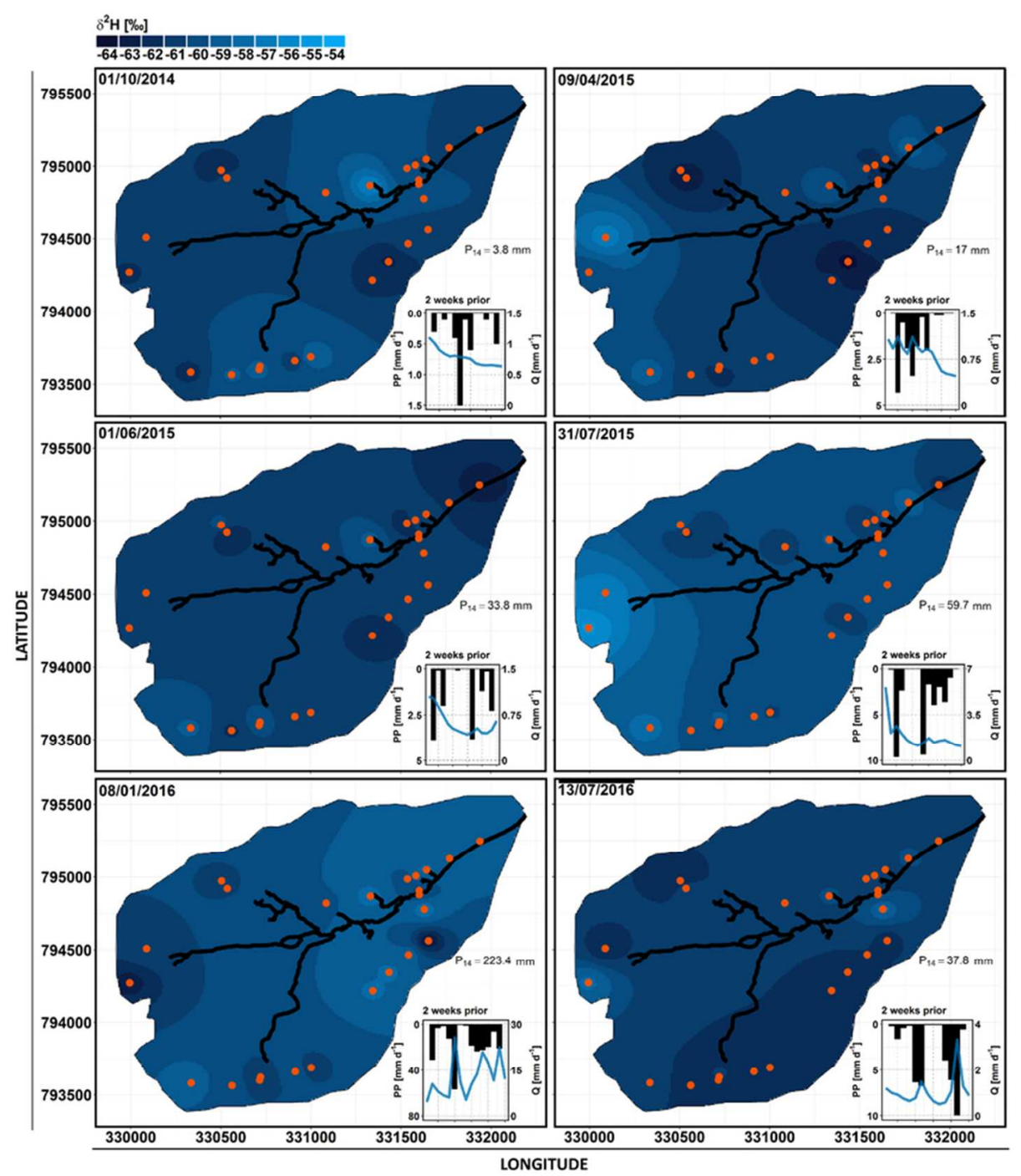

Figure 6: Interpolated $\delta^{2} \mathrm{H}$ signal of the 20 springs \& seepages samples. We integrated deeper well sample for the interpolation on the 08/01/2016 \& 13/07/2016. Insets show precipitation and discharge 14 days prior the sampling date and the sum of precipitation of the 14 days prior sampling (P14).

$$
38 \times 42 \mathrm{~mm}(600 \times 600 \mathrm{DPI})
$$




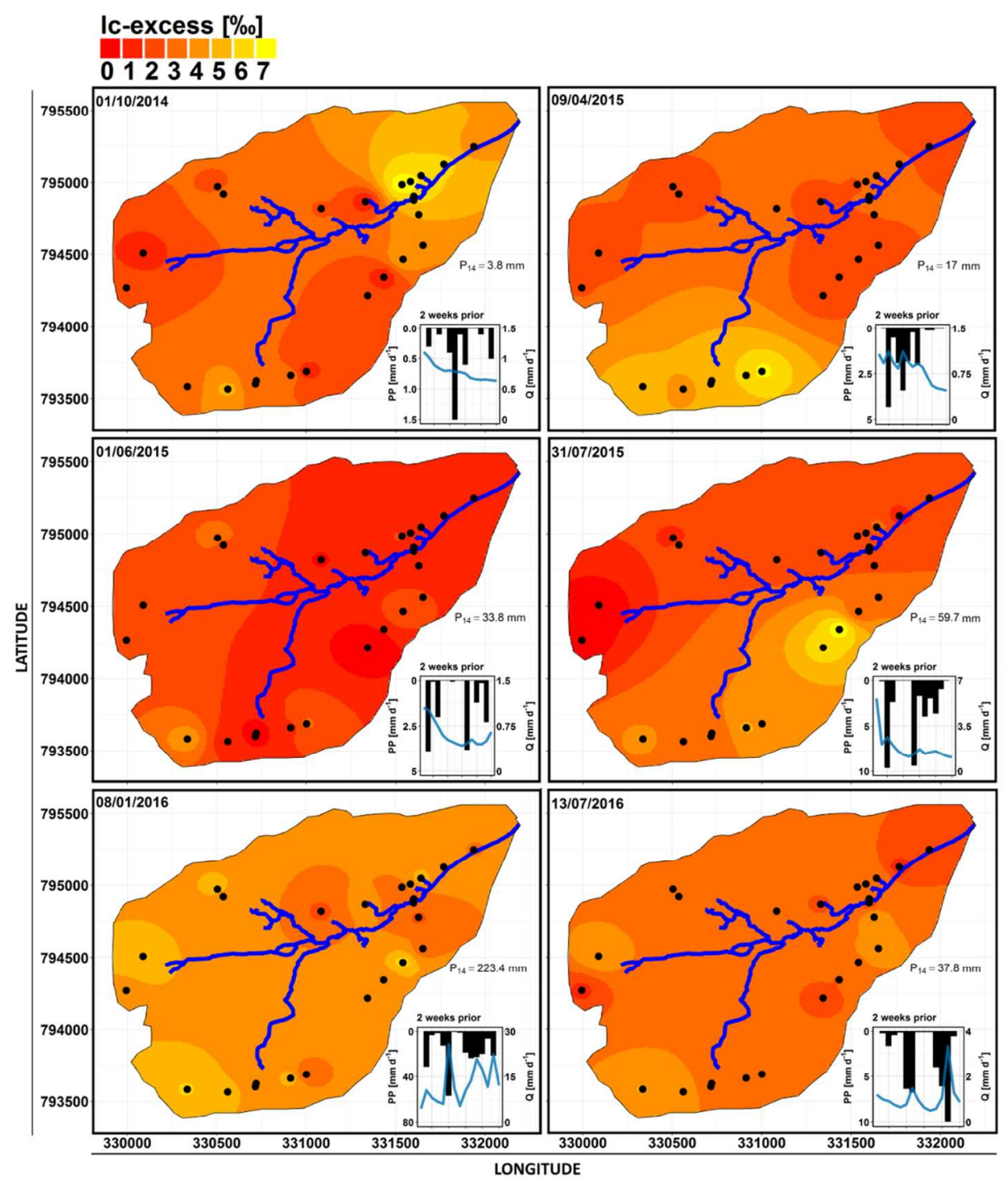

Figure 7: Interpolated Ic-excess values of the 20 springs \& seepages samples. We integrated deeper well sample for the interpolation on the $08 / 01 / 2016 \& 13 / 07 / 2016$. Negative values indicate evaporative isotopic fractionation and positive values suggest moisture source differences (Landwehr and Coplen, 2006). Insets show precipitation and discharge 14 days prior the sampling date and the sum of precipitation of the 14 days prior sampling (P14).

\section{$64 \times 69 \mathrm{~mm}(600 \times 600 \mathrm{DPI})$}




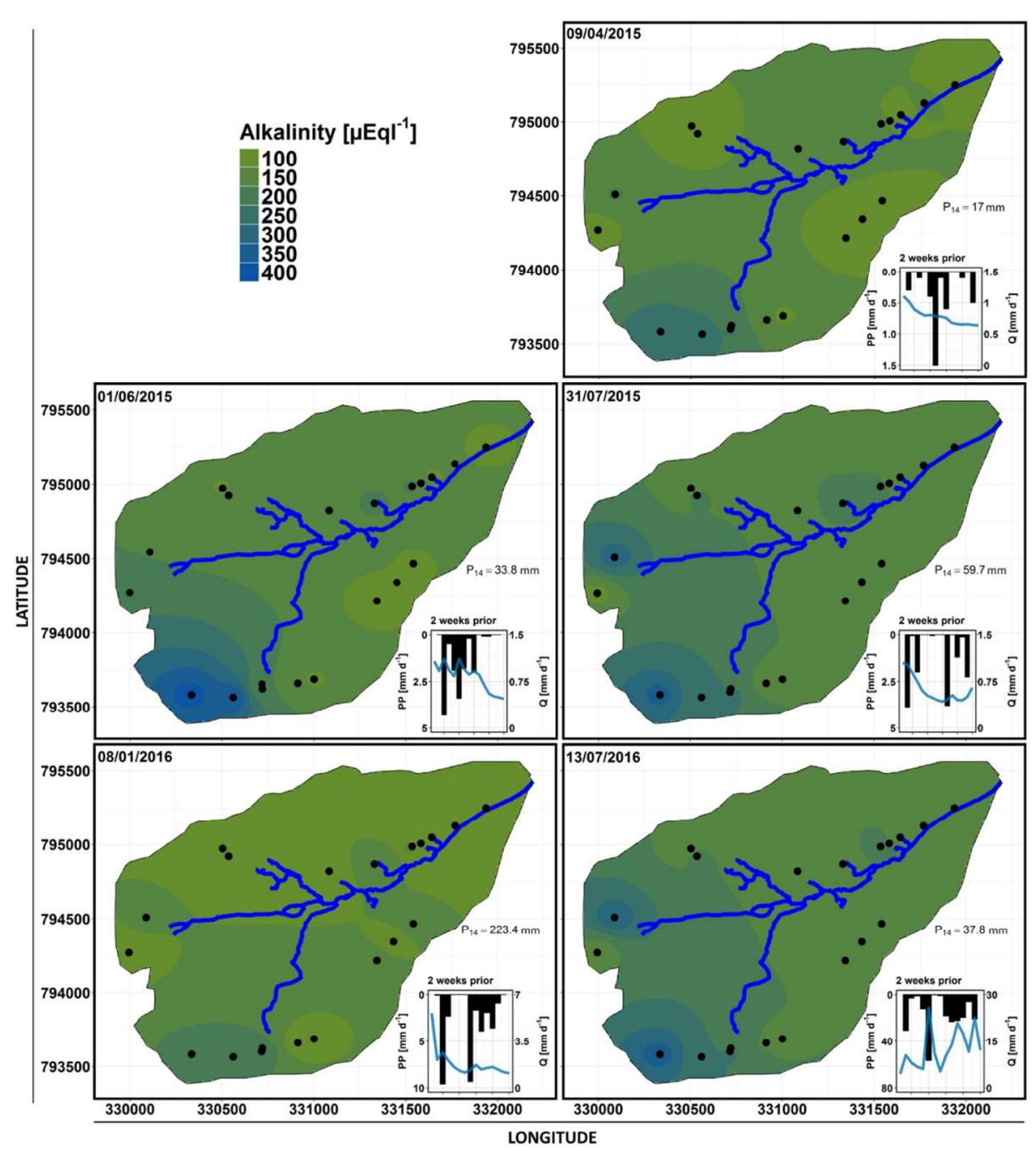

Figure 8: Interpolated alkalinity values of the 20 springs \& seepages samples. Insets show precipitation and discharge 14 days prior the sampling date and the sum of precipitation of the 14 days prior sampling (P14).

\section{$63 \times 68 \mathrm{~mm}(600 \times 600 \mathrm{DPI})$}

